IZA DP No. 6053

Diversity and Public Goods: A Natural Experiment with Exogenous Residential Allocation

Yann Algan

Camille Hémet

David Laitin

October 2011 


\title{
Diversity and Public Goods: A Natural Experiment with Exogenous Residential Allocation
}

\author{
Yann Algan \\ Sciences Po \\ and IZA \\ Camille Hémet \\ Sciences Po \\ David Laitin \\ Stanford University \\ and IZA
}

Discussion Paper No. 6053

October 2011

\author{
IZA \\ P.O. Box 7240 \\ 53072 Bonn \\ Germany \\ Phone: +49-228-3894-0 \\ Fax: +49-228-3894-180 \\ E-mail: iza@iza.org
}

\begin{abstract}
Any opinions expressed here are those of the author(s) and not those of IZA. Research published in this series may include views on policy, but the institute itself takes no institutional policy positions.

The Institute for the Study of Labor (IZA) in Bonn is a local and virtual international research center and a place of communication between science, politics and business. IZA is an independent nonprofit organization supported by Deutsche Post Foundation. The center is associated with the University of Bonn and offers a stimulating research environment through its international network, workshops and conferences, data service, project support, research visits and doctoral program. IZA engages in (i) original and internationally competitive research in all fields of labor economics, (ii) development of policy concepts, and (iii) dissemination of research results and concepts to the interested public.
\end{abstract}

IZA Discussion Papers often represent preliminary work and are circulated to encourage discussion. Citation of such a paper should account for its provisional character. A revised version may be available directly from the author. 


\begin{abstract}
Diversity and Public Goods: A Natural Experiment with Exogenous Residential Allocation*

This paper demonstrates the effects of ethnic and religious diversity on the quality of public spaces. Its identification strategy relies on the exogeneity of public housing allocations in France, and thereby eliminates the bias from endogenous sorting. The paper uses micro evidence of social interactions within housing blocks from the representative French Housing survey, which allows for a detailed identification of the channels through which diversity operates. Differentiating among three channels of public goods provision, the paper finds that heterogeneity in the housing block leads to low levels of sanctions for anti-social behavior and low levels of collective action to improve housing conditions, but no losses in public safety.
\end{abstract}

JEL Classification: $\quad \mathrm{H} 10, \mathrm{H} 41$

Keywords: fractionalization, public goods, collective action, discrimination

Corresponding author:

Yann Algan

Sciences Po

28 rue des Saints-Pères

75007 Paris

France

E-mail: yann.algan@sciences-po.fr

\footnotetext{
* The authors acknowledge financial support from the France-Stanford Center and the European Starting Grant (ERC) for enabling this cross Atlantic collaboration. We thank Larry Katz, Edward Miguel, Daniel Posner and seminar participants at Stanford, CA, Sciences Po, Paris and CREST (French research center in economics and statistics) for useful comments. We are grateful to Corinne Prost, head of the Employment Division at INSEE (French National Statistical Institute) for permitting access to key data through a convention between INSEE and Sciences Po.
} 


\section{Introduction}

Recent research has drawn ominous implications of cultural heterogeneity for social peace and economic growth. In US cities, the more the diversity, the less the social trust (Putnam 2007) and the lower the quality of public goods (Alesina, Baquir and Easterly 1999; Alesina and La Ferrara 2000). In Western Kenya, the greater the mixing of tribes, the less everyone is in public spiritedness, and the poorer the contributions to public goods (Miguel 2004, Miguel and Gugerty 2005). In cross-national surveys, diversity correlates with low growth in GDP and low quality of institutions (Easterly and Levine 1997, Alesina et al. 2003). Worse, Alesina and Zhuravskaya (2011) show that islands of homogeneity amid a broadly diverse country do not decrease the negative effects of diversity. These findings are depressing normatively for those who herald the gains from diversity (Page 2007); and depressing empirically, as in our globalized world, local cultural diversity is increasingly common (Dancygier 2010).

The degree of generality of these findings and the channels at work remain however to be determined. Putnam (2007) is careful to underline that his data allow him only to claim a short run correlation between diversity and trust. Miguel (2004) finds no diversity impacts on local outcomes in Tanzania, a country in which the ruling authorities have sought to ameliorate ethnic cleavages by promoting a common language. Posner (2004) shows that changed electoral rules can create broader ethnic identities thereby reducing fragmentation. Finally, Glennerster, Miguel and Rothenberg (2010) argue that the presence of strong chiefs at the local level, although reinforcing the salience of ethnicity, translates into effective inter-ethnic cooperation. It follows that the implications of cultural and ethnic diversity on economic outcomes can exhibit some variation according to the political setting and processes that create more inclusive identities.

Therefore, before we take the negative findings on public goods as generalized implications of cultural diversity for all settings, we must ascertain whether (a) the direction of causality goes from diversity to the quality of public goods; (b) religious diversity - a bigger threat to social peace in the minds of many - has the same implications as ethnic diversity; and (c) the negative implications of diversity can be ameliorated by republican public policies, that is, those that encourage common citizenship 11

This paper makes contributions on each of these questions by examing how local (block-level) ethnic and religious diversity is related to the residents' perception of the quality of public spaces. Our first contribution is to deal with the issue of causality from diversity to economic and social outcomes by exploiting the random allocation of ethnic groups within French public housing blocks. This allocation policy helps alleviate the general concern in this literature that the endogenous residential sorting of individuals on ethnic grounds biases the diversity impact. Housing policies in France over the past half-century allow for a cleaner test of this causal story than heretofore

\footnotetext{
${ }^{1}$ Republicanism refers to the policy project of the Opportunist Republicans who came to power in 1877 in the Third Republic, opposing the last vestiges of monarchism, and promoting a secular project (known as laïcité) with the goal of erasing all ascriptive ties, whether ethnic or religious, as compromising common citizenship. In today's France, republicanism opposes itself to multiculturalism.
} 
performed by providing a natural experiment of an exogenous residential allocation of ethnic groups. Due to a strongly republican ideology built into law, the French government has allocated state planned moderate cost rental apartments (HLMs - Habitations à Loyer Modéré) to natives and immigrants without concern for their cultural background, mixing people indiscriminately. Some HLM neighborhoods are consequently quite diverse, and others quite homogeneous. Furthermore, HLM inhabitants rarely move, as the rents are much lower than market rates, and movement between HLMs is quite difficult to do. Therefore, residents cannot choose whether to live nearby people like themselves; rather, they accept their placement and do their best whether next to co-ethnics or strangers. Methodologically, this means that we can take the degree of diversity in any one HLM as exogenous, and trace the implications of the housing situation to see if greater heterogeneity leads to poorer provision of public goods and social relationships in French society ${ }_{2}^{2}$

We confirm with a variety of tests that the allocation in the public housing market can be considered to a large extent as exogenous relative to ethnic characteristics. In particular, we show that the repartition of ethnic minorities across HLMs does not depart significantly from a randomly simulated distribution, contrary to what is observed in the private housing market. Besides we are able to get a sense of the bias in the estimated impact of diversity in the presence of endogenous sorting of individuals by comparing the public and the private housing markets. This paper thus makes progress on the identification of the causal impact of ethnic diversity on public goods by providing a natural experiment with exogenous residential allocation to individuals.

Naturally, this paper is not the first one to deal with the issue of causality. But previous attempts to establish causality have mainly relied on instrumental variables, since the seminal contribution of Alesina et al. (1999). However convincing the instruments might be, this strategy still raises the concern whether the instruments fulfill the exclusion restriction and do not have a direct effect on public goods. For instance, Miguel (2004) and Miguel and Gugerty (2005) use the pre-colonial patterns of settlement as instruments, assuming that these variables have no direct impact on present-day ethnic relations. More recently Glennerster et al. (2010) have also relied on historical data of fractionalization as an instrument. But since past settlement patterns are likely to have at least some direct impact on present-day ethnic relations, the identification with intrumental variables raises a concern on the ability of instruments to fulfill the exclusion restriction. Using a natural experiment with exogenous allocation of ethnic groups is thus an alternative strategy to deal with these worrisome caveats.

The second contribution of this paper is the identification of the exact nature of diversity that affects social relationships and the quality of public goods, and of the channels through which it operates at the micro level. The French public housing situation allows us to address this issue by disentangling different channels and various dimensions of diversity, both ethnic and religious, within the same natural experiment framework and at a micro level of analysis: the unit of analysis

\footnotetext{
${ }^{2}$ We are not the first to rely on the HLM sector for exogenous placement. Goux and Maurin (2006) test the neighborhood effects on education in the French context. Similar strategies to ours are employed by Oreopoulos, (2003) who examines the long-term individual economic outcomes in the Canadian context, and Katz et al. (2001) who use a randomized mobility experiment to analyze the socio-economic effects of neighborhood placement.
} 
of the surveys is at the block level which allows a much more precise analysis of how diversity shapes social relationships than the previous literature based on macro analysis at the county, regional or country levels. Available national statistics provide a unique way to differentiate the channels through which diversity could affect public goods and social relationships. The Housing Survey reports both general information on housing conditions and more specific information about the neglect of and vandalism within the public areas, about the quality of the housing, and about direct interpersonal conflicts. This enables us to explore more deeply the possible channels through which diversity affects the various outcomes. When residents report that vandalism is rife in their housing unit, we interpret this as a result of the failure on the part of residents to develop norms that would punish defectors. When residents report the breakdowns and the poor quality of basic facilities (such as heating and soundproofing), we interpret this as a result of diminished collective action for social improvement. In this case, the result may well be supported in equilibrium through recognition by the housing directorate that in ethnically or religiously heterogeneous apartments, it can permit the decline of facilities, knowing that it will not face collective action from its residents demanding better services. Finally, when residents report incidents of direct civil conflicts, we can interpret this as failure by the state to give proper police protection in selected housing establishments.

One might be worried that our analysis draw exclusively on the resident self-reports of the quality of public spaces rather than on objective outcomes. Since we have a more detailed level of analysis of public spaces at the housing block level compared to the previous literature, we do not have access to objective indicators. Without taking a definite stand on the pros and cons of self-reported measures, we claim that this approach is still relevant in our context. First, objective indicators for say violence tend to underestimate the victimization rate, since conflicts are not systemically reported to offical authorities. Understanding how ethnic diversity affects the perception of the quality and safety of public spaces is important in its own right. Besides, the household survey reports precise questions on the origins of the quality of public spaces, distinguishing between voluntary degradations, the lack of improvement of the facilities or direct violence. Finally, we show that self-reported assessments of the quality of public spaces are likely to capture part of their true quality since all the neigborhoods living in a given housing block tend to have the same appreciation, whatever their ethnic origin and individual characteristics.

One of the main results of this paper is that diversity has a much bigger impact on the failure to develop punishment norms and to organize collective action than on civil conflict, perhaps because diversity is associated with social anomie rather than inter-ethnic hatred in French housing units.

In addition to identifying the channels through which diversity operates, this paper investigates whether religious diversity - a form of diversity that has caused far more worry in Europe than ethnic - has the same implications as ethnic. One might surmise that the standard unit for ethnic diversity - the linguistic group - might have special qualities that make speakers of different languages less diversity-acceptant. For one, linguistic groups can communicate among themselves more efficiently than with outsiders, such that diversity may raise the costs of collective decision making. Second, linguistic survival of small groups requires territorial concentration, and therefore 
ethnic diversity may be seen as a threat to the core foundation of any ethno-linguistic group's solidarity. Religious diversity may yield alternative routes toward public goods failure and social relationships, but as of now we do not know whether such diversity has implications for the production and maintenance of public goods and the quality of social relationships. This paper offers a first test as to whether religious diversity (Christian vs. Muslim) has the same implications as ethnic/linguistic diversity. The French Housing surveys do not report the religious affiliation but the first names of all the members of the households within a given block. We provide tentative evidence on the role of religious diversity by distinguishing individuals with Christian Saints' first names and Muslim first names. We find that both dimensions of diversity have a negative effect on the general opinion of residents on their housing quality.

The third contribution of this paper is to take a stand on the previous literature in which the direction of the effect of ethnic diversity varies with the political setting. We test whether the results coming from western Kenya or from neighborhoods in American cities are robust to a changed policy environment. In Kenya, for example, tribal memberships are the key to resources coming from the center; therefore distrust of the ethnic other may not be the result of diversity in itself but of the ethnic patronage system that pervades Kenyan politics. Findings from the US as well, where the census and public policy recognize ethnic identifications, may highlight diversity in a way to exacerbate distrust. France, with its resolute republican ideology, may therefore be less subject to the distrust which comes from diversity. For example, in the 19th arrondissement of Paris, made famous for its diversity in the film Entre les Murs (titled "The Class" in the Englishlanguage version), still 63.5 percent of the residents were born in France. While this is significantly lower than the figure for all of Paris (82.4 percent), it demonstrates that homogeneous ghettos do not exist in Paris the way they do in the US, or Kenya ${ }^{3}$ Even in public housing, and this because the rents are so attractive to native French, we rarely find in France public housing structures that are fully ghettoized. This paper shows that in a Republican setting, the effects of ethnic and religious diversity are significant, raising questions about the efficiency of the integration process within this institutional framework, and as to whether the effects of diversity are impervious to institutional design.

The remainder of this paper is organized as follows. Section 2 presents the data. Section 3 provides various tests to assess the random nature of the allocation process of individuals across public housing units. Section 4 reports the impact of ethnic and religious diversity on public goods and social relationships in public housing. Section 5 provides additional tests of the validity of our results. Section 6 concludes.

\footnotetext{
${ }^{3}$ Data supplied by the mayor's office at the 19th district. On foreign born in Paris, see http://www.migrationinformation.org/dataHub/GCMM/Parisdatasheet.pdf
} 


\section{Presentation of the data}

\subsection{Data sets}

In this paper, we use two French national surveys: on the one hand, we use the continuous version of the French Labor Force Survey (Enquête Emploi, INSEE, hereafter the LFS) between 2003 and 2007. This dataset provides all relevant information on labor market success (hourly wage, employment status) and education. On the other hand, we mostly use the 2002 wave of the French Housing Survey (Enquête Logement, INSEE, hereafter the HS), which gives information on perceptions of the quality of the neighborhood (crime, poverty, etc.) and on quality of the public infrastructure (trash collection, working order of apartment elevators, etc.). Each dataset provides complementary features for our study that allow us to address fundamental questions of the effects of cultural heterogeneity on the quality of life $4^{4}$

First, we use the LFS to test our identification strategy. These data are areolar: they are not drawn directly from a selection of homes, but from a selection of geographical areas (aires) made up of twenty adjacent homes on average 5 Over the 2003 to 2007 period, more than 10,000 different areas were sampled. All the households within a randomly selected area were surveyed and, within each household, all persons aged fifteen or over were interviewed. That way, we can work on real neighborhoods. Moreover, we know whether the respondent was living in an HLM, if s/he had been living in her/his current HLM at least for one year or whether s/he had just moved into the neighborhood. These particular features enable us to compute the level of ethnic or cultural diversity prevailing within one's HLM neighborhood, to test our identifying assumption and to track the impact of randomized allocation of households to a given HLM.

We then use the HS to derive our main results, as it contains all the key left-hand side variables and controls for the study. However this survey suffers from an important drawback: the samples are not areolar, meaning that all the individuals living in a given geographical unit are not systematically surveyed and are randomly drawn instead. This feature implies that we cannot observe true neighborhoods in our data. It also implies that we have too few observations within each geographical unit of interest, the $\hat{\imath} l o t 6^{6}$ It becomes consequently difficult to compute significant and relevant measures of diversity in one's neighborhood.

We compensate for this drawback by using the French Population Censuses. Each HS sample is drawn from the most recent Census and the geographical units of the HS are a subsample of those of the Census. As the census provides variables such as birth country or nationality at birth, it allows us to compute representative fractionalization indexes at the block level and then to match them with the corresponding HS. Here, we compute fractionalization indexes at the block level using the

\footnotetext{
${ }^{4}$ Some of the key variables for our study are not public. The French Statistical Institute (INSEE) made their access possible as part of a convention between the INSEE and Sciences Po. We were required to make use of the "sensitive" data within the confines of INSEE.

${ }^{5}$ INSEE has chosen this sampling strategy so as to reduce the traveling expenses of those who administer the survey.

${ }^{6}$ We work at one of the smallest geographical unit, the "îlot", which is comparable to a block. We will refer to "blocks" instead of "îlots" from now on.
} 
1999 Population Census, and match them to the blocks of the 2002 HS.

Both surveys include the first names of all the members of the households, along with the country of origin of the respondent and of the respondents' parents. It is thus possible to use the first name as a proxy for identifying Muslim cultural heritage and overcome the lack of official data on the religious affiliation of individuals in France. Indeed, as research by Fryer and Levitt (2004) and Disdier, Head and Mayer (2009) suggests, names given to children are expressions of cultural identity. This measure is imperfect, though. In some countries, for example, it has been reported that non-Muslims may give their children Muslim names. Given that French national statistics do not include questions on religion, and giving a Muslim name to children from a Catholic heritage in France is surely a rare event, the data on first names in the French context is a resource worth exploiting 7

\subsection{Fractionalization indexes}

We rely on the ethno-linguistic fractionalization (hereafter ELF) index mostly used in the literature (e.g. Alesina et al. 2003) to construct our measures of French diversity relying on data from the 1999 Population Census. This traditional measure of ethnic diversity reflects the probability that two randomly drawn individuals from the population belong to different groups (previous studies looked at ethno-linguistic or religious groups). More formally, the basic fractionalization index is computed as one minus the Herfindahl index of ethno-linguistic group shares:

$$
E L F_{j}=\sum_{i=1}^{i=N} s_{i j}\left(1-s_{i j}\right)=1-\sum_{i=1}^{i=N} s_{i j}^{2}
$$

Where $s_{i j}$ is the share of group $i(i=1, \ldots, N)$ in country (or any other convenient geographic area) $j$. If the population under study is fully homogeneous, $E L F_{j}$ equals 0 and it trends to 1 as the population heterogeneity increases. It is also interesting to note that $E L F_{j}$ can increase for two reasons: it will increase with the number of ethno-linguistic groups, and it will increase the more equal the size of the groups.

As mentioned above, the Census data provide information about the country of birth and the nationality at birth of individuals, allowing us to construct two different measures of diversity. We focus here on diversity as measured by nationality at birth, computed at the block level 8 The

\footnotetext{
${ }^{7}$ There are two main reasons that make this indicator a potential good proxy for the perceived share of Muslim people at the block level. First, the transmission of Maghrebian first names associated with the Qu'ran is a natural practice for religious people. Second, the Maghrebian first name captures an additional component of the cultural background of the respondent compared to his country of origin or to the nationality at birth. To put it differently, an individual with a Maghrebian first name would be recorded in the national statistics as French if he/his parents are born in France or if he is a first generation immigrant but got naturalized. Yet his first name would sound as a direct indication that he is coming from a different cultural background than the French Christian one. Maghrebian first names are a signal of identification with the culture at large and could be as such a wider cultural proxy than religious practice. We thus take this indicator as a lower bound for the percentage of Muslims in a neighborhood.

${ }^{8}$ In the private housing sector, the allocation of individuals is likely to depend on endogenous sorting in which individuals make decisions as to where to move based in part on the ethnic composition of the whole neighborhood. Consequently, we compute the ELF for people living in the private sector taking into account all individuals in the neighborhood, including public housing inhabitants, since the choice in the private sector might depend both on
} 
distribution of diversity in French blocks is presented in Appendix A (Figure 1 and Table 12 . 9 Unsurprisingly, given that immigrants and second generation French are more likely to qualify for HLM apartments than the rooted French population due to income qualifications, HLM neighborhoods are characterized by higher levels of diversity than French neighborhoods as a whole.

\subsection{Sample characteristics}

Our results rely on the 2002 wave of the HS. Most of the variables we are interested in (those describing the quality of life within one's building or neighborhood) are given at the household level, and the dataset contains 32,156 households (corresponding to 78,791 individuals). The data show that in 2002, 39.6 percent of the French households are renters while 56 percent are owners. In our sample, 15.77 percent of the households live in an HLM, which represents 39.8 percent of the tenants. Table 1 describes the main socio-demographic characteristics of our sample, comparing households living in public and in private housing. Foreigners (or immigrants) represent a larger share in the HLM population than in the private housing population. And, as expected, HLM neighborhoods are characterized by a globally poorer socio-economic environment: the unemployment rate in public housing neighborhoods is on average more than twice as high as in the private housing neighborhoods, and individuals in HLMs are less educated and hence earn lower incomes. For instance, almost one third of the HLM adults have no diploma at all, and only 11.7 percent of them have achieved graduate studies, which is less than half the figure obtained in the private housing population.

Even focusing on public housing population, housing conditions faced by native French and immigrants differ. On average, French born individuals have a much better opinion about the quality of their housing than Maghrebians or other Africans 10 Table 2 shows that 13.8 percent of the French are very satisfied with their housing conditions, which is true for only 8.42 percent of the Maghrebians. Conversely, only 9.9 percent of the French report insufficient housing conditions versus 18.21 percent of the Maghrebians. However, the last line of Table 2 reveals that the poorer housing conditions are associated with lower levels of income, which characterizes Maghrebian and African families. For instance, households that are very happy with their housing conditions earn on average 13,300 Euros per year, while very unhappy households earn 10,127 Euros a year on average. From the last column, we observe that the average Maghrebian family earns even less than that (8,603 Euros).

diversity within the housing unit and also within the block where the housing is located. Results are similar when we compute the ELF in private housing on the basis of people living in the private sector only. Meanwhile, in the public housing sectors, households are randomly located and hence less subject to this selection issue. We therefore compute ELF for people living in an HLM on the basis of their neighbors living in the public sector only to maintain the exogeneity in the diversity indicators.

${ }^{9}$ On the HLM graph, we see that 6 percent of HLM blocks are perfectly homogeneous. This high frequency is to a large extent explained by the fact that in many blocks, we observe only very few inhabitants, increasing the chance of getting a null ELF. We keep those blocks in our main analysis, but we will see in the robustness checks section that deleting them does not affect the results, and in some specifications, strengthens them.

${ }^{10}$ We observe the same pattern when we look at more objective measures of building quality such as wall quality and dampness issues. 
Table 1: Public Housing and Private Housing population characteristics

\begin{tabular}{|c|c|c|c|}
\hline & Public Housing & Private Housing & p-value \\
\hline \multicolumn{4}{|l|}{ Birth Country } \\
\hline France & 78.63 & 88.34 & 0.000 \\
\hline Portugal & 1.72 & 1.23 & 0.028 \\
\hline Spain & 1.12 & 0.78 & 0.089 \\
\hline Italy & 0.72 & 1.10 & 0.007 \\
\hline Other E.U. country & 0.71 & 1.05 & 0.091 \\
\hline Turkey & 1.24 & 0.30 & 0.000 \\
\hline Other European country & 0.74 & 0.75 & 0.767 \\
\hline Maghreb & 11.06 & 4.14 & 0.000 \\
\hline Other African country & 2.66 & 1.06 & 0.000 \\
\hline Cambodia, Vietnam, Laos & 0.69 & 0.41 & 0.016 \\
\hline Other countries & 0.72 & 0.84 & 0.381 \\
\hline \multicolumn{4}{|l|}{ Nationality } \\
\hline French at birth & 82.02 & 92.11 & 0.000 \\
\hline French by acquisition & 5.75 & 3.33 & 0.000 \\
\hline Portuguese & 1.24 & 0.97 & 0.090 \\
\hline Spanish & 0.44 & 0.26 & 0.004 \\
\hline Italian & 0.32 & 0.34 & 0.865 \\
\hline Other E.U. nationality & 0.16 & 0.59 & 0.002 \\
\hline Turkish & 1.20 & 0.20 & 0.000 \\
\hline Other European nationality & 0.36 & 0.29 & 0.959 \\
\hline Maghrebian & 6.51 & 0.99 & 0.000 \\
\hline Other African nationality & 1.68 & 0.38 & 0.000 \\
\hline Cambodian, Vietnamese, Laotian & 0.16 & 0.07 & 0.004 \\
\hline Other nationalities & 0.16 & 0.46 & 0.016 \\
\hline \multicolumn{4}{|l|}{ Employment status } \\
\hline Employed & 58.19 & 56.11 & 0.090 \\
\hline Unemployed & 10.82 & 4.08 & 0.000 \\
\hline Retired & 20.07 & 26.5 & 0.000 \\
\hline \multicolumn{4}{|c|}{ Level of education (highest diploma obtained, individuals above 25 years old) } \\
\hline No diploma & 28.26 & 14.85 & 0.000 \\
\hline Low education & 50.62 & 48.33 & 0.009 \\
\hline Baccalaureate & 9.37 & 12.44 & 0.000 \\
\hline High education & 11.74 & 24.38 & 0.000 \\
\hline \multicolumn{4}{|l|}{ Socioprofessional group } \\
\hline Farmer & 0.76 & 6.17 & 0.000 \\
\hline Craftman, Shopkeeper & 2.56 & 9.06 & 0.000 \\
\hline Executive or other high position & 4.87 & 18.87 & 0.000 \\
\hline Intermediate occupation & 15.80 & 21.42 & 0.000 \\
\hline Employee & 31.12 & 18.10 & 0.000 \\
\hline (Factory) Worker & 44.89 & 26.36 & 0.000 \\
\hline Age (mean) & 31.50 & 39.35 & 0.000 \\
\hline Annual income (mean) & 12,846 & 18,048 & 0.000 \\
\hline
\end{tabular}

The last column reports the p-value from a t-test for the null hypothesis that the mean of a given variable is the same for the public housing and private housing populations. 


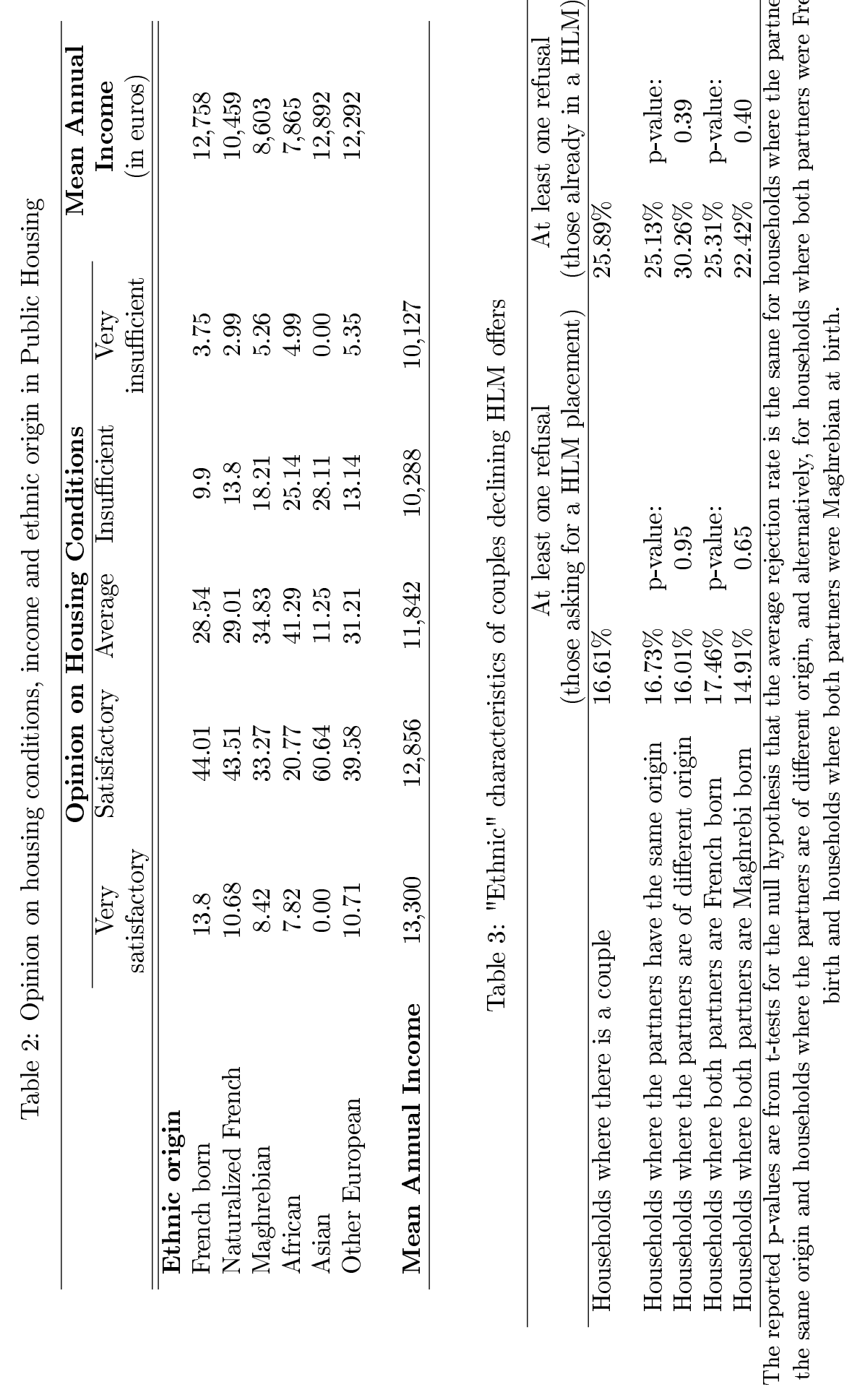




\section{The exogeneity of diversity within public housings}

The main difficulty in estimating the impact of ethnic diversity on the quality of public goods is that fractionalization presents a high risk of endogeneity, leading to biased results from naïve regressions. Indeed, individuals generally tend to self segregate: they prefer links with others like themselves, with whom they share common interests, in particular people of the same ethnicity or the same social background. This phenomenon implies that if people can choose the area where they live, they would rather move into neighborhoods where people are similar to themselves.

Thus, if individuals who are not constrained with respect to the location of their home choose to gather along ethnic lines, then the richest individuals will be able to move into the most homogeneous neighborhoods (as their choice will be relatively unconstrained). Therefore, the level of diversity of the neighborhoods is probably endogenous to wealth, and any estimates on the implications of diversity for wealth (or factors correlated with wealth) will be biased. To be more specific, if the only wealthy families that live in diverse settings are those who have a taste for diversity, the true effect of diversity on social outcomes should be smaller in absolute terms (less negative). In order to address this downward bias issue, one must study individuals who are assigned their place of residence without consideration of their cultural, social or economic status - that is, exogenously 11 We begin with the assumption that assignment within HLM's in France is largely random in regard to ethnicity and religion, and that the costs of moving are so high that residential mobility within the HLM sector is limited. Naturally, there is an endogenous sorting among the population who are eligible for an HLM assignment since the rents are considerably lower in public housing than in private housing. But among the population eligible for public housing, households are expected to be exogenously allocated across the different housing blocks.

This random allocation has been mainly documented in sociology and law so far. The research conducted by Bernardot (2008) on immigrant housing in France lends support to this assumption of exogeneity. His work emphasizes the importance in urban planning for housing policy in France, associated with the theories of Le Corbusier. Le Corbusier insisted that France must avoid the homogeneous ghettos of urban landscapes elsewhere, and should therefore allocate housing in a random manner, not permitting family networks to grow within housing establishments. These ideas were translated into state regulations. Supporting this assumption, Simon's (2003) research shows that residential mobility within the HLM sector is a practical impossibility. Similarly, the lawyers Rouquette and Lipietz (1991) show that the rules of allocation of lodging, prohibiting "localism", and the high administrative barriers that effectively prohibit exchanges of lodgings except for the changing spatial needs of families, make the allocation of housing largely random with respect to the ethnic origins of the applicants. In the economics literature, Goux and Maurin (2006) show that the educational achievement of the children of newcomers in a public housing project is uncorrelated with that of the current residents. Individuals cannot self-select in public

\footnotetext{
${ }^{11}$ Combes, Decreuse, Schmutz and Trannoy (2010 working paper) use customer discrimination theory to show that owners will tend to discriminate against ethnic minorities when renting their apartment, bringing new evidence of why any causal claim of ethnic diversity on public goods in the private housing market would be biased.
} 
housings according to the educational achievement of the neighbors' children. In contrast, the authors find a strong self-selection on those educational characteristics in the private housing sector 12

\subsection{Identification of the exogeneity of diversity in public housing}

We first present the basic arguments in favor of the exogeneity assumption. In France, the population eligible for public housing is very large: the only requirements are to be legally living in France (as a French citizen or migrant with a valid residence permit) and to be living under a certain threshold of income per unit of consumption, which is usually rather high. For instance, in 2009, this threshold was between 36,748 and 50,999 Euros per year for a four-person family, depending on the region of residence; the upper figure is nearly 3,000 Euros higher than the average disposable income of four-person households in 2007. In addition, rents are considerably lower in public housing than in private housing, so that the turnover is very low. Consequently, the number of eligible families is about three times as large as the available space in HLMs, and the waiting periods are rather long: the $2002 \mathrm{HS}$ reports that over one third of the population asking for a public housing unit had been waiting for more than one year. As a result, we expect that households usually apply for housing to several HLM administrators ${ }^{13}$ in order to increase their chances of assignment to a unit and rarely decline an HLM offer when it comes. People therefore have very little control over the neighborhood they inhabit, giving some initial support to our assumption that the distribution of households within public housing is close to what would be obtained through a randomized experiment.

Formal tests lend further confidence that HLM assignment is ethnically random. Our first test consists in addressing the disturbing (for our assumption) fact that 16 to 24 percent ${ }^{14}$ of households declined at least one HLM offer ${ }^{15}$ This suggests selection bias. However, if this refusal rate is the same among ethnically diverse and ethnically homogeneous households, the selection story would be less worrisome. The idea behind our test is the following: if households decline HLM offers because they have strong preferences for ethnic homogeneity (and therefore decline offers because the neighborhood is too fractionalized), then we would expect that ethnically mixed households (supposedly the more tolerant of ethnic mixing) refuse HLM proposals less systematically than other households. On the contrary, if the rejection rate is similar for mixed and homogeneous couples, then the refusal must be motivated by other criteria (size of the house, distance from work, or some

\footnotetext{
${ }^{12}$ For an alternative view, see SOS-racisme (2009). This report suggests administrative limits to diversity, but does not dispute randomness up to those limits.

${ }^{13} 43.6 \%$ of households looking for a HLM placement have addressed their demand to the Town Hall, $62.3 \%$ of them have directly contacted a HLM office.

${ }^{14} 16 \%$ corresponds to the share of households living in the private section but willing to move into an HLM who declined an offer when it came, while $24 \%$ corresponds to households already living in an HLM but asking for a different one.

${ }^{15} \mathrm{An}$ additional concern was that $47.9 \%$ of households having turned down an offer declared that one of the major reasons for this decision was they found the local environment unpleasant, which could be interpreted as a distaste for diversity, creating endogeneity. The other possible answers were: inconvenient place, rent too expensive, low quality building, and apartment not corresponding to household needs.
} 
other factor not correlated with ethnicity).

The frequencies displayed in the first three lines of Table 3 (obtained from the HS data) are favorable to the idea that homogeneous households do not turn down HLM offers more often than those with a mixed couple. In fact, when we regress "refusal", the estimated coefficient on the "same-origin" dummy is non-significant. Performing a test of equality of means between the rejection rates of the two groups leads to acceptance of the null hypothesis (equality of rejection rates between mixed and homogeneous households). In addition, we performed the same tests comparing homogeneous native French couples and homogeneous Maghrebian couples. Indeed, it could be the case that households from a minority group prefer to live in a more heterogeneous area (even if the couple is homogeneous) so as to increase their chance to have neighbors from the same minority group. Here again, the t-test is in favor of no statistical difference between the two groups' refusal rates. The corresponding frequencies are reported in the last two lines of Table 3 for illustrative purposes. To sum up, this first test shows that the high refusal rates of HLM offers is not driven by distaste for diversity ${ }^{16}$

An alternative test of the validity of our identifying assumption focuses on individuals who moved into an area within the previous year, using the LFS data. We now pay attention to the correlation between their hourly wages and the level of diversity of the area into which they just moved. Without prior beliefs over agents' preferences, if individuals have a taste for or against homogeneity when their choice is not constrained by legal rules, there should be a significant relationship between the level of ethnic diversity prevailing in their neighborhood and their wages. Indeed, in the private housing market, the richer the individual, the more able he is to choose his neighborhood. So if the level of diversity of the area enters his preferences, there should be a correlation between his revenues and the area's fragmentation. Within public housing as well, because they are more recent or have a better location, some neighborhoods are more expensive than others. Therefore, even on the public housing market, some families are more constrained than others, and one can wonder whether the richest HLM inhabitants have some control over the diversity of their neighborhood. In a first step, we focus on individuals having just moved in a non HLM home. We compute the fractionalization index of the area in which they move (taking into account only the individuals having lived there for more than one year), and look at the correlation between this index and the hourly wage of newly arrived individuals 17 In the private housing market, there is a very strong negative relationship between income and diversity (the estimated coefficient is -0.14 and is significant at the $1 \%$ leve 18 .

In a second step, we restrict the sample to individuals having moved into an HLM within the past year. We use the fractionalization index within the HLM neighborhood, testing again the

\footnotetext{
${ }^{16}$ Instead, we could think that an "unpleasant local environment" refers to such things as being too close to a large road, or lacking in green spaces.

${ }^{17}$ The coefficients correspond to the OLS estimates of diversity among former inhabitants on log hourly earnings, controlling for the department of residence.

${ }^{18}$ The results are not displayed but are available upon request.
} 
assumption that the administrative organs allocate the housing randomly with respect to ethnicity. The simple OLS regression reveals that there is no significant correlation between the income of individuals moving into public housing and the diversity of nationalities existing within the neighborhood. This additional test is thus favorable to the assumption that ethnic diversity within HLM neighborhoods is exogenous 19

Table 4: Correlation between new inhabitants' birth country and share of the area population born in the same country

Public Housing Private Housing

(1)

New inhabitant born in France

Share of block population born in France

New inhabitant born in Maghreb

Share of block population born in Maghreb

New inhabitant born in Africa (except for Maghreb)

Share of block population born in Africa

New inhabitant born in a Mediterranean country

Share of block population born in a Mediterranean country

New inhabitant born in Eastern Europe

Share of block population born in Eastern Europe

New inhabitant born in a German-speaking country

Share of block population born in a German-speaking country

New inhabitant born in Asia

Share of block population born in Asia
$1.011^{* *}$

$-0.0208$

0.112

$(0.136)$
$0.600^{* * *}$

$0.283^{* * *}$

0.0957

0.129

0.262

$(0.191)$

Each of the coefficients is estimated from a separate regression of individual's birth country on the share of each ethnic group in the block into which he has just settled. The reported coefficients are estimates for the share of the individual's own ethnic group. The coefficient for other ethnic groups shares are available from authors upon request. Additional controls are department fixed effects, wage, and level of education. Regressions include 10,365 observations in the private housing sector and 895 observations in the public housing sector. Robust standard errors adjusted for block clustering are in parentheses. $* * * \mathrm{p}<0.01, * *$ $\mathrm{p}<0.05, * \mathrm{p}<0.1$

The third test is also based on LFS data and assesses whether there is a link between the birth country of individuals moving into a new area and the share of the area's "long term" population born in the same country. We expect a significant relationship between the two in the private housing market, where location choice is relatively unconstrained, but not in the public housing sector. We control for the socio-economic characteristics of individuals (their wage and education

\footnotetext{
${ }^{19}$ If we reverse the dependent and the explanatory variables, the significance levels of the correlation coefficients remain the same.
} 
levels) and include department fixed effects. In the private housing sector (Column (2), Table 4), a significant relationship between one's origin and the share of similar neighbors show up for most of the regions of origins. In contrast, in the public housing sector (Column (1), Table 4), there is no statistically significant relationship between the birth country of the individual and the share of

the "long term" population in the area. Self segregation in the public sector seems to be a much less important concern for our identification strategy than in the private sector.

\subsection{Alternative Test of random allocation in public housing: Monte Carlo simulation}

We end this section with a more direct statistical test of randomness which consists in simulating a random distribution of the HLM population and to compare it to the actual distribution. We perform this test using the 2003 to 2007 Labor Force Surveys in which the smallest geographic area observed consists in an exhaustive neighborhood. This particular structure enables us to perform a comprehensive test of population distribution across neighborhoods.

Our identification strategy is based on random allocation of individuals across the different public housing within each given department. Since most of the public housing are administrated at the department level, we test whether for each department, the allocation of housing across the various HLM neighborhoods is blind to the ethnic origin of the tenant. To do this, we run Monte-Carlo simulations allocating randomly the HLM population of each department to the available HLM neighborhoods in the department. In that way, we are able to compute, for each neighborhood, the various ethnic group shares that we would observe if the allocation was perfectly random across the blocks within a given city, and to compare them to the shares actually observed in our data. In what follows, we explain more specifically how we proceed.

The basic idea is to pool the HLM population from every neighborhood in a department, and to reallocate it randomly to the HLMs across all neighborhoods, taking into account the demographic structure of each neighborhood. In other words, our simulation randomly assigns the HLM population across the HLM neighborhoods of a department, respecting the actual size of each neighborhood. Consider for instance, an (hypothetical) department with two HLM neighborhoods, one with ten inhabitants, the other with five. In each neighborhood, we are able to compute the actual share of native French and of Maghrebis. The simulation then randomly chooses one neighborhood to fill, and randomly allocates the corresponding number of individuals to this neighborhood. In this very simple example, five out of the fifteen individuals are randomly selected to form the simulated five-inhabitants neighborhood, the remaining ten then forming the simulated ten-inhabitants neighborhood. We finally compare the real and the simulated distributions of the shares of natives French and of Maghrebi across the various neighborhoods.

In our data, we make sure to run this test based on neighborhoods in which we observe at least five households. In order to avoid composition effects due to existing families, we also restrict our 
sample to household heads. We finally restrict our sample to the neighborhoods where we observe at least five percent of Maghrebis to focus on areas where there is at least some diversity. After simulating the distribution of ethnic group shares as explained above, we compare the actual and the simulated distributions of native French and Maghrebi shares across neighborhoods: we first run a simple t-test of equality of means, then we use a more demanding test of equality of distributions, the Kolmogorov-Smirnov test. The corresponding results are displayed in Table 5 . The figures displayed represent the percentage of departments for which the actual and simulated distributions of ethnic shares across neighborhoods are similar, i.e. those for which we cannot reject the null hypothesis at the $10 \%$ level. The labels in the first column indicate the ethnic group for which we compare the shares distributions across neighborhoods. The second column shows that there is no department for which we can reject the null hypothesis that the real and simulated distributions of the ethnic group shares have equal means. The Kolmogorov-Smirnov test results are displayed in the third column. According to this test, the actual and simulated distribution of native French shares across HLM neighborhoods are similar in 98.61 percent of the departments. When we focus on Maghrebi shares, we find that the two distributions are alike in 98.61 percent of departments as well. All in all, those tests are in line with the idea that the distribution of the households eligible for an HLM placement within the public housing blocks is close to random regarding ethnicity, and thus supports our identification assumption 20

In addition, we performe the same test on education. Goux et Maurin (2006) have shown that the allocation across HLM within a given department is exogeneous along this dimension, by showing the absence of correlation between the level of education of the existing residents and that of the new comers. The last line of Table 5 confirm this result. We focus on the allocation of households heads across HLM in each department depending on their educational achievement (lower or higher than primary school). The distribution of the population across HLM along this characteristic is close to a random allocation.

Table 5: \% of departments for which the actual and simulated distributions of Native French and Maghrebi shares across neighborhoods are similar in public housing.

\begin{tabular}{ccc}
\hline & t-tests & K.S-test \\
\hline Native French & $100 \%$ & $97.61 \%$ \\
Maghrebi & $100 \%$ & $98.90 \%$ \\
Both ethnic groups & $100 \%$ & $97.22 \%$ \\
Primary Education & $100 \%$ & $98.18 \%$ \\
\hline
\end{tabular}

\footnotetext{
${ }^{20}$ Algan et al. (2011) provides an alternative test of the exogenous allocation of households in the public housing sector. They regress households' ethnic characteristics on fixed effects associated with the different public housings within each department. The random allocation test consists in performing standard F-test on the null hypothesis that the fixed effects are jointly not statistically different from zero. In the case of endogenous residential sorting in some public housings, the fixed effects associated with those blocks should be statistically significantly correlated with the household characteristics, and the F-test would be rejected. They find that in more than 85 percent of the departments the F-test reject the null-hypothesis of a correlation between ethnic characteristics of the households and public housing fixed effects.
} 


\section{Results}

This section estimates the causal impact of diversity on public goods, by focusing on the public housing sector where households are exogenously allocated. The regressions presented in this section control for a large set of individual characteristics, including age, gender, average years of education, whether the respondent is inactive, employed or unemployed, household size, and respondent's income level in 2002 Euros. We also control for French citizenship (a dummy variable equal to 1 if French citizenship and 0 otherwise) and the respondent's country (or region) of birth, distinguishing between France, European countries, the Maghreb, Sub-Saharan Africa, Asia and all others. We also include the number of apartments in the building, since the size and the number of occupants might affect the ability of the households to coordinate for improving the commons or to enforce norms.

An important issue in our regressions is whether the extent of fractionalization is picking up various dimensions of the environment where people are living, including the extent of inequality and the unemployment rate (Alesina and La Ferrara, 2002) or the socio-economic background of the neighborhood (Goux and Maurin, 2006). From the INSEE and Nicole Tabard (2002) we therefore include a very detailed classification in 27 categories of the socio-economic environment of each area. These classifications provide a weighted indicator of the occupations, the sectors, the education and the income of each neighborhood. From the Census we also include the average unemployment rate of the block. All the results are based on OLS estimates, with robust standard errors clustered at the block level.

\subsection{The effect of fractionalization on housing conditions}

Let us first examine the impact of diversity on the general satisfaction about housing conditions. As shown in the previous section, the degree of diversity in public housing can be considered as exogenous, and allows us to measure the causal effect of diversity. Let $j$ indicate blocks and $k$ indicate households. For each outcome, we estimate the following equation:

$$
Y_{j k}=\alpha_{k}+\beta_{k} E L F_{j}+\gamma_{k} X_{k}+\delta_{k} Z_{j}+\varepsilon_{j k}
$$

where $Y_{j k}$ denotes the housing outcome we are interested in as stated by household $k$ in block $j$, $E L F_{j}$ is the level of ethnic diversity in the block, $X_{k}$ is a vector of household characteristics (described above) and $Z_{j}$ a vector of socio-economic characteristics of the block. In all the regressions, we also control for department fixed effects, since our identification strategy is based on random allocation of individuals across the different public housing within each given department.

The main variable of interest in this section is the overall opinion about housing conditions. From the HS, we use the question: "In general how do you judge the quality of your housing conditions?" The variable takes on values from 1 , for very good, to 5 for very bad. 
Table 6: Ethnic Diversity, Religious Diversity and Public Goods (public housing)

\begin{tabular}{|c|c|c|c|c|}
\hline & \multicolumn{2}{|c|}{ Ethnic Diversity } & \multicolumn{2}{|c|}{ Religious Diversity } \\
\hline & $(1)$ & $(2)$ & $(3)$ & $(4)$ \\
\hline \multicolumn{5}{|c|}{ General Opinion on Housing Conditions } \\
\hline & $\begin{array}{c}0.897^{* * *} \\
(0.091)\end{array}$ & $\begin{array}{c}0.551^{* * *} \\
(0.130)\end{array}$ & $\begin{array}{c}0.330^{* * *} \\
(0.080)\end{array}$ & $\begin{array}{c}0.175^{*} \\
(0.090)\end{array}$ \\
\hline Observations & 4,379 & 4,379 & 5,104 & 4,379 \\
\hline R-squared & 0.082 & 0.137 & 0.063 & 0.134 \\
\hline \multicolumn{5}{|c|}{ Index for Neglect of Public Areas } \\
\hline & $\begin{array}{c}1.697^{* * *} \\
(0.326)\end{array}$ & $\begin{array}{c}1.734^{* * *} \\
(0.412)\end{array}$ & $\begin{array}{c}0.715^{* * *} \\
(0.238)\end{array}$ & $\begin{array}{c}0.485^{* *} \\
(0.229)\end{array}$ \\
\hline Observations & 1,693 & 1,693 & 1693 & 1693 \\
\hline R-squared & 0.073 & 0.187 & 0.056 & 0.178 \\
\hline \multicolumn{5}{|c|}{ Index for Poor Quality of Housing } \\
\hline & $\begin{array}{c}2.085^{* * *} \\
(0.192)\end{array}$ & $\begin{array}{c}1.137^{* * *} \\
(0.260)\end{array}$ & $\begin{array}{c}0.755^{* * *} \\
(0.168)\end{array}$ & $\begin{array}{c}0.226 \\
(0.160)\end{array}$ \\
\hline Observations & 3,797 & 3,797 & 3,797 & 3,797 \\
\hline R-squared & 0.090 & 0.168 & 0.059 & 0.163 \\
\hline \multicolumn{5}{|c|}{ Index for Civil Conflicts } \\
\hline & $\begin{array}{c}0.347^{* * *} \\
(0.131)\end{array}$ & $\begin{array}{c}0.062 \\
(0.179)\end{array}$ & $\begin{array}{c}0.134 \\
(0.129)\end{array}$ & $\begin{array}{c}0.0001 \\
(0.130)\end{array}$ \\
\hline Observations & 4,388 & 4,379 & 4,379 & 4,379 \\
\hline $\begin{array}{l}\text { R-squared } \\
\text { Socio-economic }\end{array}$ & 0.017 & 0.060 & 0.015 & 0.060 \\
\hline Background of area & No & Yes*** & No & Yes*** \\
\hline Department fixed effects & No & Yes*** & No & Yes*** \\
\hline
\end{tabular}

Each coefficient is estimated from a separate regression, according to equation 2 The four dependent variables considered include the answer to the general opinion question and the three indices that were derived from principal component analysis as described in section 4.2. Each index is regressed on either ethnic diversity or religious diversity, controlling for the usual household and neighborhood characteristics unless otherwise indicated. Robust standard errors adjusted for block clustering are in parentheses. ${ }^{* * *}$ $\mathrm{p}<0.01,{ }^{* *} \mathrm{p}<0.05,{ }^{*} \mathrm{p}<0.1$

The first panel of Table 6 looks at the role of ethnic diversity on opinion about housing conditions and reports the estimates for the public housing sector with exogenous allocation of individuals. In the first specification (column 1), we only control for individual characteristics and the size of the building. Column 2 reports the estimates obtained when including controls for the unemployment rate and the socio-economic background of the neighborhood at the block level, as well as department fixed effects. Table 13 in Appendix B reports the full set of estimates for these regressions.

In both specifications, the variable ethnic diversity is statistically significant at the 1 percent level. According to the most comprehensive specification (Column 2), an increase by one standard 
deviation in ethnic diversity is associated with an increase by 9.77 percent in the probability of having a bad opinion of the housing conditions.

The last two columns of Table 6 look at the role of religious diversity on the opinion about housing conditions. Column 3 reports the estimates in the private sector controlling for individual characteristics. Column 4 reports the same estimates when controlling for covariates at the block or department levels. The indicator for religious diversity, as previously justified, is the percentage of households, within the block, that have at least one individual with a Maghrebian first name.

Here we see that our indicator for religious diversity is positively and statistically significantly correlated with the probability that the respondent has a low opinion about the housing conditions. With religious diversity, here with the most comprehensive specification (Column 4), an increase by one standard deviation in religious diversity is associated with an increase by 4 percent in the probability of having a bad opinion of the housing conditions.

\subsection{Decomposing the effect of fractionalization: Neglect of Public Areas, Housing Quality and Civil Conflicts}

\subsubsection{Identification of the channels}

This section looks further at the various dimensions of housing conditions that could be affected by fractionalization. We run an exploratory analysis to extract the main dimensions with which the various questions reported in the HS correlate the most. We identify those factors by running a principal component analysis on the whole set of questions related to the quality of public goods and to social relationships. The full list of questions is reported in Appendix E. The principal component analysis lets the correlation patterns among the various questions emerge endogenously from the data, rather than grouping them in an arbitrary way. We select (following the Kaiser criterion) three main factors with eigenvalues higher than one that emerged from the principal component analysis of the relevant survey questions.

Table 7 reports those three factors and the rotated matrix of correlations between those factors and each question. Three main patterns of correlation emerge, to which we refer as "neglect of the public areas", "quality of housing" and "civil conflict".

Giving names to each of the three factors identified, Table 8 reports descriptive statistics of the various questions. For each variable, a lower value represents a better outcome (e.g. higher care of the commons, less graffiti, better soundproofing...). 
Table 7: Principal component analysis

\begin{tabular}{lccc}
\hline & Factor 1 & Factor 2 & Factor 3 \\
\hline Care of the commons & 0.142 & 0.225 & 0.053 \\
Voluntary degradations of the commons & 0.675 & 0.172 & 0.091 \\
Graffiti on the walls & 0.209 & -0.126 & 0.023 \\
Trash in the commons & 0.247 & 0.047 & 0.085 \\
Broken doors in the commons & 0.591 & 0.166 & 0.123 \\
Broken lights in the commons & 0.564 & 0.072 & 0.031 \\
Degradation of mail boxes & 0.528 & 0.130 & 0.034 \\
Broken elevators & 0.528 & -0.031 & -0.041 \\
Quality of the building's facade & -0.038 & 0.239 & -0.030 \\
Problem with heating in the building & -0.007 & 0.336 & 0.029 \\
Quality of soundproofing & 0.042 & 0.703 & 0.004 \\
Noise disturbance during the day in the housing & 0.060 & 0.831 & 0.052 \\
Noise disturbance at night in the housing & 0.113 & 0.807 & 0.105 \\
Victim or witness of aggression in the neighborhood & 0.098 & 0.136 & 0.746 \\
Victim or witness of robbery in the neighborhood & -0.006 & 0.028 & 0.810 \\
\hline
\end{tabular}

Table 8: Descriptive statistics for each outcome (public housing)

\begin{tabular}{lcc}
\hline & Mean (std dev) & Values \\
1. Neglect of the Public Areas & & \\
Care of the commons & $1.592(0.752)$ & 1 to 3 \\
Sacking & $1.637(0.777)$ & 1 to 3 \\
Graffiti & $0.666(0.471)$ & $0-1$ \\
Garbage on the floor & $0.487(0.499)$ & $0-1$ \\
Broken glass & $0.353(0.478)$ & $0-1$ \\
Broken doors & $0.330(0.470)$ & $0-1$ \\
Broken light bulbs & $0.243(0.429)$ & $0-1$ \\
Broken mailboxes & $0.399(0.489)$ & $0-1$ \\
Broken elevators & $0.220(0.414)$ & $0-1$ \\
& & \\
2. Quality of Housing & $2.432(0.962)$ & 1 to 5 \\
Condition of the outside walls & $1.980(0.822)$ & 1 to 3 \\
Quality of soundproofing & $1.594(0.747)$ & 1 to 3 \\
Noisy in daytime & $1.374(0.626)$ & 1 to 3 \\
Noisy in nigh time & $0.202(0.401)$ & $0-1$ \\
Cold in the apartment & \multicolumn{2}{|c}{} \\
& $0.094(0.292)$ & $0-1$ \\
3. Civil Conflict & $0.081(0.273)$ & $0-1$ \\
Robberies & \multicolumn{2}{l}{ Aggressions }
\end{tabular}

According to the questions, we have between 1,937 and 5,
between 1543 and 26,967 for private housing households. 


\subsubsection{Estimation of the channels}

We run a principal component analysis on each group of questions, and take the first principal components of each, ending up with three indices. We create three summary indices from the three groups of questions identified in the previous section. The higher the indices, the more unfavorable are the outcomes. Because the magnitudes of the separate outcomes are often easier to interpret than those of the principal component analysis, we also report the estimates for each question taken separately in Appendix D (Table 18). We checked the robustness of the results by looking at alternative summary indices, taking the sum of the questions belonging to each group, or performing a mean effect analysis for each group. The estimates for these alternative indices are reported in Appendix $\mathrm{C}$, yielding similar results.

We now return to Table 6 which summarizes the results for the three indices ${ }^{21}$. For each index, we run separate regressions on ethnic diversity and on religious diversity controlling for the usual household and neighborhood characteristics unless otherwise indicated, according to equation 2 .

The second panel of Table 6 reports the effect of ethnic and religious diversity on the synthetic index Neglect of Public Areas. We report the result in the public housing environment, without (columns 1 and 3) and then with controls at the local level (columns 2 and 4). The effect of ethnic diversity is always statistically significant at the 1 percent level, and is substantively sizeable. In the full-specification (column 2), a one standard deviation increase in ethnic diversity is associated with a rise by 31.1 percentage point of the index Neglect of Public Areas, which represents 17.3 percent of the total standard deviation of this index. The effect of ethnic diversity represents two-thirds of the effect of local unemployment, and is much more significant than any individual characteristic. Education, though the most statistically significant individual variable, is so at the 5 percent level; and a one standard deviation increase in education is associated with a rise by 12.7 percentage points of the Neglect index.

The last two columns of Table 6 report the estimates for the religious diversity index. In the most general specification (column 4), religious diversity is found to be statistically significant at the 5 percent level. The effect of religious diversity is substantively less important than ethnic diversity. A one standard deviation increase in religious diversity is associated with a rise by 12 percentage points in the Neglect of Public Areas index, which accounts for 6 percent of the standard deviation of this index.

The third set of regressions reports the effect of fractionalization on the index of Poor Housing Quality. Columns 1 and 2 show that ethnic diversity is statistically significant at the 1 percent level for all specifications. A one standard deviation increase in ethnic diversity is associated with a rise by 20.3 percentage points in the index of Housing Quality. It is also worthwhile to stress that ethnic diversity has a smaller impact on outcomes related to the quality of housing than on the previous index of the Neglect of Public Areas. In the case with covariates at the local level (column 2), the

\footnotetext{
${ }^{21}$ The coefficient estimates for the control variables are not reported here but are very similar to those reported in Table 13 in Appendix B. The full regression results are available upon request.
} 
effect of ethnic diversity on Housing Quality represents two-thirds of the effect of diversity on the neglect of public areas. Column 3 shows that religious diversity has a statistically significant effect on the quality of housing when we control for individual characteristics only. But the relationship loses statistical power when we control for local covariates, in particular for the unemployment rate at the local level.

The last panel of Table 6 reports the results for our synthetic index of Civil Conflict, capturing direct aggression and robberies. Remarkably, it shows that ethnic diversity has a statistically significant effect on civil conflicts in the public housing sector only when we control for individual characteristics (column 1). But the relationship is no longer significant as soon as we control for the unemployment rate and/or the socio-economic background of the neighborhood. This finding is on line with Fearon and Laitin (1996), who argue that despite inter-ethnic relations being generally more tense, in-group policing mechanisms typically keep violence off of the equilibrium path. The last column confirms this finding for religious diversity.

The broad picture drawn in the three previous sets of regressions is largely confirmed by the regressions of each separate normalized outcome (as shown in Appendix D, Table 18). Although diversity has no significant impact on a few outcomes, such as broken glass or broken doors in the commons, we still have a very strong negative effect of diversity on all other negligence or housing quality outcomes in the public sector.

In sum, fractionalization operates differently on the three various dimensions of the housing environment identified above. We distinguish three main channels. The effect of ELF on Neglect of Public Areas is probably related to the failure in heterogeneous settings to develop norms that would assign responsibility for the punishment of unruly residents guilty of vandalism. This behavior by residents would be a natural consequence of the lack of social contacts, or, the lack of closure in the network, as argued by Coleman (1988) ${ }^{22}$ The effect of ELF on Poor Housing Quality is more related to the failure to generate collective action for social improvement. This could well be sustained (though we have no direct evidence to support this) by beliefs in the housing directorate that in heterogeneous apartments it needs not maintain public goods to high standards because the likelihood of collective action against it is minimal. In this sense, the resulting poor housing quality associated with ethnic and religious diversity can be seen as an equilibrium in which the lack of expectations of collective action would fail to incentivize the directorate to make costly improvements. The effect of the ELF on aggression seems more related to either in-group policing mechanisms that cross-cut ethnic and religious groups or to the power of the state police in deterring civil violence in public areas. The valued-added of our experiment is to provide a unique framework to test the specific role of ELF on these various outcomes in the same context. The basic results are that ELF has a key impact on the norms that punish defectors, and to a lesser extent on free riders, but with no effect on civil conflict ${ }^{23}$ From this, we deduce that on average, higher levels of

\footnotetext{
${ }^{22}$ Supporting our intuition, many households living in the public housing sector report having "no relationship at all" with their neighbors.

${ }^{23}$ This finding is consistent with the additional question on the quality of the relationship with the neighborhood
} 
diversity trigger worse outcomes on public good provision and civic behavior relative to things, but not to persons.

\section{$5 \quad$ Additional tests}

\subsection{Measuring the bias with endogenous residential sorting}

As shown in section 3, the residential allocation in public housing can be considered as exogenous relative to ethnic backgrounds. In contrast, the extent of diversity in private housing is partly the result of an endogenous choice from movers. By comparing the effect of diversity in the private housing sector with the effect of diversity in the public one, we can get a sense of the bias associated with the traditional naïve OLS estimator found in the literature. We expect the results to be biased downward. Indeed, for this specific population, location choice is likely to be at least partly determined by diversity in the neighborhood.

We regress the different outcomes (general opinion on housing conditions as well as the three indices identified in section 4.2) on ethnic and religious diversity as in our favorite specification, but focusing this time on the population living in the private housing sector. When focusing only on the private housing population, to keep things comparable with the evidence from the public sector, we exclude owners from the sample, and focus on households living in apartment dwellings.

Table 9 reports the naïve estimators when we focus on the private sector with endogenous allocation of individuals. Column 1 shows the results for ethnic diversity, controlling for individual and neighborhood characteristics. Estimates for religious diversity are reported in column 2. The first set of regressions indicates that a one standard deviation increase in ethnic diversity is associated with an increase by 8.3 percent in the probability of having a bad opinion of the housing conditions. This is slightly lower than what is found in the corresponding regression on the public housing population (9.7 percent). Similarly, the naïve estimator with endogenous sorting is not statistically significant for religious diversity (column 2). These first findings suggest that the naïve estimator tends to downplay the true impact of fractionalization on the overall opinion about housing conditions.

The estimates reported in the second and third panels are even more striking: column 1 shows that an increase by one standard deviation in ethnic diversity is associated with a rise by 18.9 percentage point of the index Neglect of Public Areas (which represents 15.8 percent of the total standard deviation of this index in the private housing area). This is almost twice as low as what was obtained in the public housing population (31.1 percentage points) ${ }^{24}$ Similarly, a one standard deviation increase in ethnic diversity is associated with a rise by 11.3 percentage point of the index

provided by the housing survey. We typically find that ELF is positively and significantly correlated with the fact of having no interpersonal relationships at all with their neighbors, but it displays no correlation with reports by respondents as to whether they have good or bad relationships. ELF seems thus to be associated with social anomie rather than social conflicts. However, this correlation holds only when we control for individual characteristics.

${ }^{24}$ When we run the regression on the full private housing sample (including owners and people living in individual houses), we find an effect three times lower than in the public housing. 
for Poor Housing Quality. Here again, the naïve effect is twice as small as the effect measured in a setting where diversity is more exogenous. These results reveal the importance of overcoming endogenous sorting when seeking to identify the effects of heterogeneity on public goods. The relation between religious diversity and the indices for Neglect of Public Areas and Poor Quality of Housing is no longer statistically significant in the presence of endogenous allocation in the private sector (column 2), leading to the same conclusion.

Table 9: Ethnic Diversity, Religious Diversity and Public Goods (private housing)

\begin{tabular}{|c|c|c|}
\hline & $\begin{array}{l}\text { Ethnic Diversity } \\
(1)\end{array}$ & $\frac{\text { Religious Diversity }}{(2)}$ \\
\hline \multicolumn{3}{|c|}{ General Opinion on Housing Conditions } \\
\hline & $0.591^{* * *}$ & 0.138 \\
\hline & $(0.180)$ & $(0.122)$ \\
\hline Observations & 4141 & 4141 \\
\hline R-squared & 0.165 & 0.162 \\
\hline \multicolumn{3}{|c|}{ Index for Neglect of Public Areas } \\
\hline & $1.334^{* *}$ & 0.498 \\
\hline & $(0.567)$ & $(0.461)$ \\
\hline Observations & 727 & 727 \\
\hline R-squared & 0.321 & 0.316 \\
\hline \multicolumn{3}{|c|}{ Index for Poor Quality of Housing } \\
\hline & $0.796^{* *}$ & -0.023 \\
\hline & $(0.351)$ & $(0.255)$ \\
\hline Observations & 3023 & 3023 \\
\hline R-squared & 0.116 & 0.114 \\
\hline \multicolumn{3}{|l|}{ Index for Civil Conflict } \\
\hline & $0.643^{* * *}$ & 0.038 \\
\hline & $(0.234)$ & $(0.174)$ \\
\hline Observations & 4141 & 4141 \\
\hline R-squared & 0.064 & 0.062 \\
\hline \multicolumn{3}{|l|}{ Socio-economic } \\
\hline Background of area & Yes*** & Yes*** \\
\hline Department fixed effects & Yes*** & Yes*** \\
\hline
\end{tabular}

Each coefficient is estimated from a separate regression, according to equation 2 To keep things comparable with the public sector, we exclude owners from the sample, and focus on households living in apartment dwellings. The three dependent variables considered are the three indices from the principal component analysis. Each index is regressed on either ethnic diversity or religious diversity, controlling for the usual household and neighborhood characteristics unless otherwise indicated. Robust standard errors adjusted for block clustering are in parentheses. ${ }^{* * *} \mathrm{p}<0.01,{ }^{* *} \mathrm{p}<0.05,{ }^{*} \mathrm{p}<0.1$

The last panel of Table 9 reports estimates for our Civil Conflicts index. Contrary to what we found above for the other indices, the estimate for ethnic diversity in the private sector is significant 
at the 1 percent level, while it was not significant in the public housing. Column 1 shows that a one standard deviation increase in ethnic diversity is linked to a rise by 9.1 percentage point of the index of Civil Conflicts. We have no explanation for this anomalous result, and it merits analysis in future work on heterogeneity 25

\subsection{Fractionalization and ethnic shares}

The basic regressions measure ethnic diversity using a standard ELF index, controlling for individual and local characteristics. Yet, as suggested by Vigdor (2002), it is crucial to control for ethnic group shares to get a more comprehensive set of covariates for diversity. Column 1 of Table 10 reports the results controlling for ethnic group shares 26 It turns out that the estimated impact of ELF is now even stronger than in the previous specifications, confirming the robustness of our result along this dimension.

Moreover, we run regressions replacing the fractionalization index by ethnic groups shares (column 2 of Table 10, and by ethnic group shares and their square (column 3 of Table 10 ${ }^{27}$ controlling for the usual individual and local characteristics. Only one group (Maghrebian) seems to have a significantly negative effect on opinions on housing conditions: the higher the share of Magrhebis in an block (relative to the share of French), the more likely individuals are to complain about their housing conditions. However, this negative effect decreases with the share of Maghrebis. From this result, we infer that our measure of diversity reflects not only the actual ethnic composition of the neighborhood, but also that some ethnic groups might have different effects on their self-reported perceptions of the quality of public spaces when they become a majority of the neighborhood population. However, this result does not call into question the effect of diversity per se on which we have already reported (column 1 of Table 10 .

\subsection{Relevance of self-reported quality of public goods}

A final concern is related to the subjective nature of the variables used in our database. Perhaps people are just happier when they are surrounded by people more like themselves, and this is reflected in their answer to the quality of housing. We provide here several tests challenging this alternative explanation. First, we run our main regression including interaction terms between diversity and the various ethnic groups, to see whether different groups react in different ways to the level of diversity of their neighborhood. Column 2 of Table 11 shows that there does not seem to be a different effect for the various groups. The coefficient for diversity remains unchanged (see column 1 for the baseline specification).

\footnotetext{
${ }^{25}$ We have several conjectures on why heterogeneity does not correlate with increasing interpersonal violence, but as readers will see, this is a question requiring future research.

${ }^{26}$ In the results displayed in Table 10 , we aggregated the various nationalities at birth into six different categories for ease of reading. The results were not affected when we included the shares for all nationalities used to compute our index instead.

${ }^{27}$ Share of native French is the omitted category
} 
Then we concentrate on actual differences between "pure French" households ${ }^{28}$ and fully Maghrebian households' opinion on housing conditions. In particular, we interact the dummies of being in a fully native French household or being in a fully Maghrebi household with the ELF: none of the coefficients is significant (see Table 11. column 3). This suggests that for any given level of diversity, there is no significant difference in the answer given by pure French and fully Maghrebian households. In other words, the idea that bad opinions of housing conditions are driven by average bad feeling due to being surrounded by foreigners can be rejected. Moreover, including those additional controls only slightly affects the magnitude of the ethnic diversity coefficient, and does not affect its direction or its significance.

Thus, our results are robust to important variations in econometric specification, they hold for subjective as well as more objective outcomes, and the results for the subjective outcomes reflect far more than the fact that people do not like living around foreigners. We also showed that while some ethnic groups can act as bad apples when they become a majority in a neighborhood, including this factor does not erase the pure diversity effect.

\section{Conclusion}

This paper exploits French public housing policy as a natural experiment to identify the causal effect and the channels through which diversity affects the quality of public goods. We use the exogenous allocation of households within public housing with respect to ethnic and religious characteristics in France to overcome the bias from endogenous residential sorting that plagues the previous empirical literature on fractionalization. The French housing experiment provides in addition a unique micro level of analysis within housing blocks, allowing a detailed analysis of the channels through which diversity operates. We find that fractionalization has a negative impact on the norms that punish defectors, leading to higher levels of vandalism in the housing commons. Fractionalization also undermines collective action for the improvement of the quality of housing. But in our context, fractionalization has no effect on civil conflicts, diversity being associated with social anomie within the housing blocks rather than violent confrontations among neighbors.

This natural experiment calls for future research on the specific role of national institutions in mitigating or magnifying the effect of ethnic and religious diversity on the provision of public goods. France is a country with a republican tradition that resolutely refuses to reify ethnic identification as a strategy to prevent the ethnification of everyday life. Yet we find a significant negative effect of diversity on public goods in this institutional setting, as the association found in the US where multiculturalist institutions regulate ethnic relations (Putnam 2007) and in cases where public institutions are weak (Alesina and La Ferrara 2005). This results raises a puzzle on the the general power of institutional arguments seeking to account for variation in the provision of public goods

\footnotetext{
${ }^{28}$ Both children and parents were born French in France
} 
attributed to ethnic and religious heterogeneity.

Table 10: Ethnic Diversity and General Opinion on Housing conditions - Robustness Checks

\begin{tabular}{|c|c|c|c|}
\hline \multirow{3}{*}{$\overline{\text { Ethnic Diversity }}$} & \multicolumn{3}{|c|}{ Opinion on Housing Conditions in HLM } \\
\hline & (1) & (2) & (3) \\
\hline & $\begin{array}{c}1.699^{* * *} \\
(0.529)\end{array}$ & & \\
\hline \% Maghrebian & $\begin{array}{c}-1.238^{*} \\
(0.706)\end{array}$ & $\begin{array}{c}0.878^{* * *} \\
(0.283)\end{array}$ & $\begin{array}{c}2.553^{* * *} \\
(0.524)\end{array}$ \\
\hline$\%$ African & $\begin{array}{l}-1.860^{*} \\
(1.099)\end{array}$ & $\begin{array}{c}0.757 \\
(0.820)\end{array}$ & $\begin{array}{c}0.723 \\
(1.435)\end{array}$ \\
\hline$\%$ Asian & $\begin{array}{c}-2.602^{* *} \\
(1.309)\end{array}$ & $\begin{array}{c}0.299 \\
(0.949)\end{array}$ & $\begin{array}{c}0.158 \\
(1.825)\end{array}$ \\
\hline \% European & $\begin{array}{c}-3.065^{* * *} \\
(1.003)\end{array}$ & $\begin{array}{l}-0.212 \\
(0.491)\end{array}$ & $\begin{array}{l}-1.432 \\
(0.965)\end{array}$ \\
\hline$\%$ Other nat. & $\begin{array}{r}-1.677^{*} \\
(0.859)\end{array}$ & $\begin{array}{c}0.474 \\
(0.503)\end{array}$ & $\begin{array}{c}0.00658 \\
(0.870)\end{array}$ \\
\hline Gender & $\begin{array}{l}-0.023 \\
(0.032)\end{array}$ & $\begin{array}{l}-0.0258 \\
(0.0324)\end{array}$ & $\begin{array}{l}-0.0270 \\
(0.0323)\end{array}$ \\
\hline Age & $\begin{array}{c}-0.004^{* * *} \\
(0.0012)\end{array}$ & $\begin{array}{c}-0.0041^{* * *} \\
(0.0012)\end{array}$ & $\begin{array}{c}-0.0041^{* * *} \\
(0.0012)\end{array}$ \\
\hline Education & $\begin{array}{c}-0.019^{* * *} \\
(0.0072)\end{array}$ & $\begin{array}{c}-0.0205^{* * *} \\
(0.00729)\end{array}$ & $\begin{array}{c}-0.0205^{* * *} * \\
(0.0072)\end{array}$ \\
\hline Income & $\begin{array}{c}0.000^{* *} \\
(0.000)\end{array}$ & $\begin{array}{c}0.000^{* *} \\
(0.000)\end{array}$ & $\begin{array}{c}0.000^{*} \\
(0.000)\end{array}$ \\
\hline Unemployed & $\begin{array}{c}0.066 \\
(0.053)\end{array}$ & $\begin{array}{l}0.0775 \\
(0.053)\end{array}$ & $\begin{array}{c}0.067 \\
(0.053)\end{array}$ \\
\hline Inactive & $\begin{array}{l}-0.053 \\
(0.045)\end{array}$ & $\begin{array}{l}-0.052 \\
(0.046)\end{array}$ & $\begin{array}{l}-0.054 \\
(0.045)\end{array}$ \\
\hline Household Size & $\begin{array}{c}0.099 * * * \\
(0.012)\end{array}$ & $\begin{array}{c}0.099^{* * *} \\
(0.012)\end{array}$ & $\begin{array}{c}0.099 * * * \\
(0.012)\end{array}$ \\
\hline Building Size & $\begin{array}{c}0.0003 \\
(0.0003)\end{array}$ & $\begin{array}{c}0.0003 \\
(0.0003)\end{array}$ & $\begin{array}{c}0.0003 \\
(0.0003)\end{array}$ \\
\hline Naturalized French & $\begin{array}{l}-0.0384 \\
(0.0650)\end{array}$ & $\begin{array}{l}-0.0367 \\
(0.0657)\end{array}$ & $\begin{array}{l}-0.0295 \\
(0.0648)\end{array}$ \\
\hline
\end{tabular}

Robust standard errors adjusted for block clustering are in parentheses *** $\mathrm{p}<0.01,{ }^{* *} \mathrm{p}<0.05,{ }^{*} \mathrm{p}<0.1$ 
Table 10: Continued

\begin{tabular}{|c|c|c|c|}
\hline & \multicolumn{3}{|c|}{ Opinion on Housing Conditions } \\
\hline & $(1)$ & $(2)$ & $(3)$ \\
\hline European & $\begin{array}{c}0.0670 \\
(0.0902)\end{array}$ & $\begin{array}{c}0.0664 \\
(0.0912)\end{array}$ & $\begin{array}{c}0.0696 \\
(0.0905)\end{array}$ \\
\hline Maghrebian & $\begin{array}{c}-0.101 \\
(0.0685)\end{array}$ & $\begin{array}{c}-0.101 \\
(0.0686)\end{array}$ & $\begin{array}{c}-0.101 \\
(0.0684)\end{array}$ \\
\hline African & $\begin{array}{c}0.120 \\
(0.142)\end{array}$ & $\begin{array}{c}0.129 \\
(0.142)\end{array}$ & $\begin{array}{c}0.126 \\
(0.142)\end{array}$ \\
\hline Asian & $\begin{array}{l}-0.605^{*} \\
(0.309)\end{array}$ & $\begin{array}{c}-0.592^{*} \\
(0.312)\end{array}$ & $\begin{array}{c}-0.592^{*} \\
(0.309)\end{array}$ \\
\hline Other Nationality & $\begin{array}{c}0.638 \\
(0.632)\end{array}$ & $\begin{array}{c}0.625 \\
(0.633)\end{array}$ & $\begin{array}{c}0.627 \\
(0.636)\end{array}$ \\
\hline Unemployment rate & $\begin{array}{c}1.117^{* * *} \\
(0.177)\end{array}$ & $\begin{array}{c}1.175^{* * *} \\
(0.176)\end{array}$ & $\begin{array}{c}1.121^{* * *} \\
(0.176)\end{array}$ \\
\hline$(\% \text { Maghrebi })^{2}$ & & & $\begin{array}{c}-4.589 * * * \\
(1.219)\end{array}$ \\
\hline$(\% \text { African })^{2}$ & & & $\begin{array}{c}-2.167 \\
(7.833)\end{array}$ \\
\hline$(\% \text { Asian })^{2}$ & & & $\begin{array}{c}-2.450 \\
(13.97)\end{array}$ \\
\hline$(\% \text { European })^{2}$ & & & $\begin{array}{c}6.526 \\
(4.472)\end{array}$ \\
\hline$(\% \text { Other Nat })^{2}$ & & & $\begin{array}{c}0.940 \\
(2.916)\end{array}$ \\
\hline $\begin{array}{l}\text { Socio-economic } \\
\text { background of areas } \\
\text { Department }\end{array}$ & Yes*** & Yes*** & Yes*** \\
\hline fixed effects & Yes*** & Yes*** & Yes*** \\
\hline Constant & $\begin{array}{c}2.124^{* * *} \\
(0.164)\end{array}$ & $\begin{array}{c}2.167^{* * *} \\
(0.166)\end{array}$ & $\begin{array}{c}2.156^{* * *} \\
(0.167)\end{array}$ \\
\hline Observations & 4,379 & 4,379 & 4,379 \\
\hline R-squared & 0.140 & 0.137 & 0.141 \\
\hline
\end{tabular}

Robust standard errors adjusted for block clustering are in parentheses $* * * \mathrm{p}<0.01,{ }^{* *} \mathrm{p}<0.05,{ }^{*} \mathrm{p}<0.1$ 
Table 11: Are results driven by some major ethnic groups disliking being around foreigners?

\begin{tabular}{|c|c|c|c|}
\hline & \multicolumn{3}{|c|}{ Opinion on Housing Conditions } \\
\hline & (1) & $(2)$ & $(3)$ \\
\hline Ethnic Diversity & $\begin{array}{c}0.551^{* * *} \\
(0.130)\end{array}$ & $\begin{array}{c}0.553^{* * *} \\
(0.141)\end{array}$ & $\begin{array}{c}0.529^{* * *} \\
(0.155)\end{array}$ \\
\hline Male & $\begin{array}{l}-0.0216 \\
(0.0328)\end{array}$ & $\begin{array}{c}-0.0211 \\
(0.0329)\end{array}$ & $\begin{array}{c}-0.0223 \\
(0.0329)\end{array}$ \\
\hline Age & $\begin{array}{c}-0.00410^{* * *} \\
(0.00127)\end{array}$ & $\begin{array}{c}-0.00410^{* * *} \\
(0.00127)\end{array}$ & $\begin{array}{c}-0.00398^{* * *} \\
(0.00129)\end{array}$ \\
\hline Education & $\begin{array}{c}-0.0196^{* * *} \\
(0.00727)\end{array}$ & $\begin{array}{c}-0.0196^{* * *} \\
(0.00727)\end{array}$ & $\begin{array}{c}-0.0189^{* * *} \\
(0.00722)\end{array}$ \\
\hline (ln)-Income & $\begin{array}{c}-0.0554^{*} \\
(0.0317)\end{array}$ & $\begin{array}{c}-0.0571^{*} \\
(0.0317)\end{array}$ & $\begin{array}{l}-0.0504 \\
(0.0317)\end{array}$ \\
\hline Unemployed & $\begin{array}{c}0.0625 \\
(0.0550)\end{array}$ & $\begin{array}{c}0.0632 \\
(0.0550)\end{array}$ & $\begin{array}{c}0.0605 \\
(0.0550)\end{array}$ \\
\hline Inactive & $\begin{array}{c}-0.0598 \\
(0.0474)\end{array}$ & $\begin{array}{c}-0.0599 \\
(0.0476)\end{array}$ & $\begin{array}{l}-0.0622 \\
(0.0473)\end{array}$ \\
\hline Household size & $\begin{array}{c}0.0991^{* * *} \\
(0.0125)\end{array}$ & $\begin{array}{c}0.0990^{* * *} \\
(0.0126)\end{array}$ & $\begin{array}{c}0.0892^{* * *} \\
(0.0150)\end{array}$ \\
\hline Building size & $\begin{array}{c}0.000351 \\
(0.000338)\end{array}$ & $\begin{array}{c}0.000357 \\
(0.000339)\end{array}$ & $\begin{array}{c}0.000333 \\
(0.000344)\end{array}$ \\
\hline French nationality & $\begin{array}{c}-0.0433 \\
(0.0653)\end{array}$ & $\begin{array}{c}-0.0338 \\
(0.141)\end{array}$ & \\
\hline ELF ${ }^{*}$ French nationality & & $\begin{array}{c}-0.0301 \\
(0.367)\end{array}$ & \\
\hline European origin & $\begin{array}{c}0.0506 \\
(0.0905)\end{array}$ & $\begin{array}{c}0.0539 \\
(0.203)\end{array}$ & \\
\hline ELF ${ }^{*}$ European origin & & $\begin{array}{r}-0.0120 \\
(0.548)\end{array}$ & \\
\hline Maghrebian origin & $\begin{array}{c}-0.102 \\
(0.0679)\end{array}$ & $\begin{array}{r}-0.0701 \\
(0.188)\end{array}$ & \\
\hline
\end{tabular}

Robust standard errors adjusted for block clustering are in parentheses

${ }^{* * *} \mathrm{p}<0.01,{ }^{* *} \mathrm{p}<0.05,{ }^{*} \mathrm{p}<0.1$ 
Table 11: Continued

\begin{tabular}{|c|c|c|c|}
\hline \multirow{3}{*}{ ELF * Maghrebian origin } & \multicolumn{3}{|c|}{ Opinion on Housing Conditions } \\
\hline & (1) & (2) & (3) \\
\hline & & $\begin{array}{c}-0.0739 \\
(0.404)\end{array}$ & \\
\hline African origin & $\begin{array}{c}0.121 \\
(0.142)\end{array}$ & $\begin{array}{l}-0.146 \\
(0.330)\end{array}$ & \\
\hline ELF ${ }^{*}$ African origin & & $\begin{array}{c}0.682 \\
(0.763)\end{array}$ & \\
\hline Asian origin & $\begin{array}{c}-0.617^{* *} \\
(0.308)\end{array}$ & $\begin{array}{c}-0.0993 \\
(0.804)\end{array}$ & \\
\hline $\mathrm{ELF}^{*}$ Asian origin & & $\begin{array}{l}-1.235 \\
(1.318)\end{array}$ & \\
\hline Other origin & $\begin{array}{c}0.623 \\
(0.634)\end{array}$ & $\begin{array}{c}0.933 \\
(1.197)\end{array}$ & \\
\hline ELF $*$ Other origin & & $\begin{array}{l}-1.527 \\
(4.544)\end{array}$ & \\
\hline Unemployment rate & $\begin{array}{c}1.178^{* * *} \\
(0.177)\end{array}$ & $\begin{array}{c}1.174^{* * *} \\
(0.177)\end{array}$ & $\begin{array}{c}1.170^{* * *} \\
(0.177)\end{array}$ \\
\hline "Pure French" household & & & $\begin{array}{c}-0.0251 \\
(0.0571)\end{array}$ \\
\hline ELF * "Pure French" household & & & $\begin{array}{c}-0.0299 \\
(0.170)\end{array}$ \\
\hline Maghrebian household & & & $\begin{array}{c}0.179 \\
(0.259)\end{array}$ \\
\hline ELF $*$ Maghrebian household & & & $\begin{array}{l}-0.406 \\
(0.561)\end{array}$ \\
\hline Department FE & Yes*** & Yes*** & Yes*** \\
\hline Socio-Eco Background & Yes*** & Yes*** & Yes*** \\
\hline Constant & $\begin{array}{c}3.719^{* * * *} \\
(0.359)\end{array}$ & $\begin{array}{c}3.734^{* * *} \\
(0.361)\end{array}$ & $\begin{array}{c}3.737^{* * * *} \\
(0.351)\end{array}$ \\
\hline Observations & 4,379 & 4,379 & 4,379 \\
\hline R-squared & 0.137 & 0.138 & 0.136 \\
\hline
\end{tabular}

Robust standard errors adjusted for block clustering are in parentheses

*** $\mathrm{p}<0.01,{ }^{* *} \mathrm{p}<0.05,{ }^{*} \mathrm{p}<0.1$ 


\section{Appendix}

\section{A. Fractionalization index in French blocks}

Table 12: Fractionalization by nationality at birth in French blocks

\begin{tabular}{lccccc}
\hline & & 1999 Census & & \multicolumn{2}{c}{ 2002 Housing Survey } \\
& Whole France & Private Housing & HLM Population & Whole France & HLM Population \\
\hline Mean & 16.65 & 14.29 & 27.68 & 16.11 & 25.32 \\
Median & 11.82 & 10.29 & 25.18 & 11.9 & 23.47 \\
Std Dev & 15.33 & 13.36 & 18.75 & 14.2 & 17.94 \\
Minimum & 0 & 0 & 0 & 0 & 0 \\
Maximum & 91.83 & 91.83 & 91.3 & 84.93 & 80.25 \\
N & $6,643,287$ & $5,027,235$ & $1,616,052$ & 28,757 & 4,465 \\
\hline
\end{tabular}

Figure 1: Fractionalization by nationality at birth within French private and public housing blocks, 1999 Census
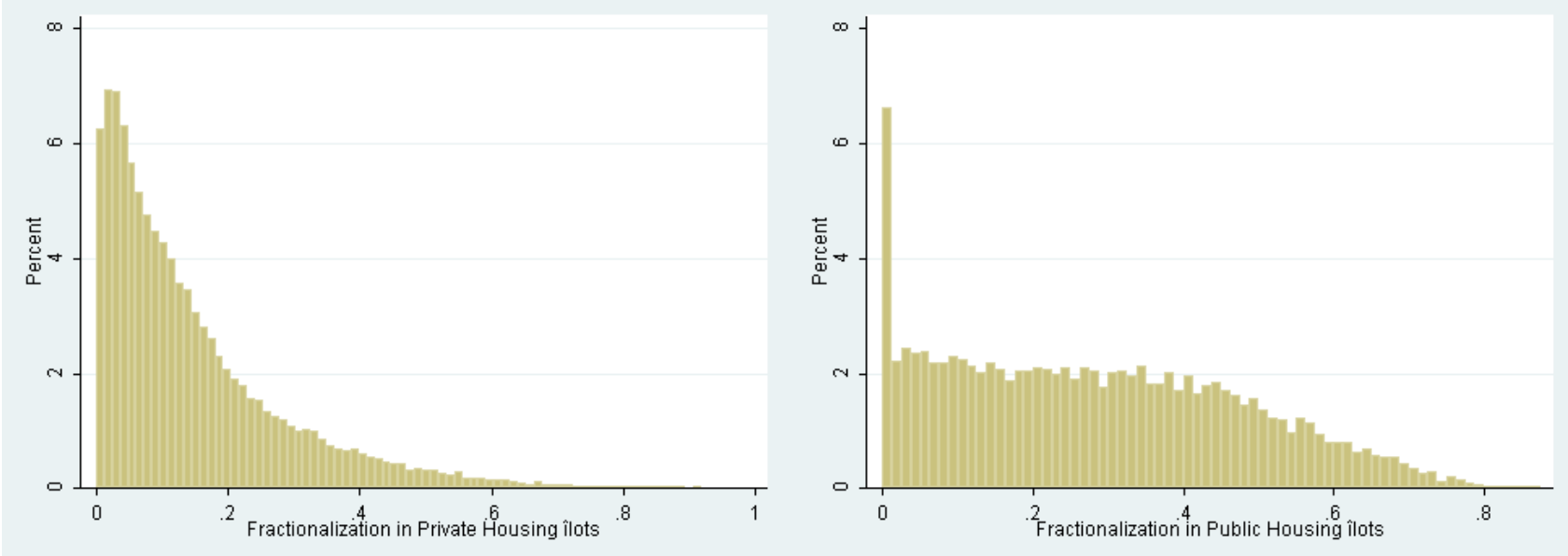


\section{B. Full regression results}

Table 13: Relationship between Ethnic Diversity and Opinion on Housing conditions

\begin{tabular}{|c|c|c|}
\hline & \multicolumn{2}{|c|}{$\begin{array}{c}\text { General opinion on Bad Housing Conditions } \\
\text { Public Housing }\end{array}$} \\
\hline & $(1)$ & $(2)$ \\
\hline \multirow[t]{2}{*}{ Ethnic Diversity } & $0.897^{* * *}$ & $0.551^{* * *}$ \\
\hline & $(0.0917)$ & $(0.130)$ \\
\hline \multirow[t]{2}{*}{ Male } & -0.00897 & -0.0216 \\
\hline & $(0.0330)$ & $(0.0328)$ \\
\hline \multirow[t]{2}{*}{ Age } & $-0.00536^{* * *}$ & $-0.00410^{* * *}$ \\
\hline & $(0.00125)$ & $(0.00127)$ \\
\hline \multirow[t]{2}{*}{ Education } & $-0.0274^{* * *}$ & $-0.0196^{* * *}$ \\
\hline & $(0.00690)$ & $(0.00727)$ \\
\hline \multirow[t]{2}{*}{ (ln)-Income } & $-0.117^{* * *}$ & $-0.0554^{*}$ \\
\hline & $(0.0315)$ & $(0.0317)$ \\
\hline \multirow[t]{2}{*}{ Unemployed } & $0.102^{*}$ & 0.0625 \\
\hline & $(0.0548)$ & $(0.0550)$ \\
\hline \multirow[t]{2}{*}{ Inactive } & -0.0146 & -0.0598 \\
\hline & $(0.0473)$ & $(0.0474)$ \\
\hline \multirow[t]{2}{*}{ Household size } & $0.0921^{* * *}$ & $0.0991^{* * *}$ \\
\hline & $(0.0125)$ & $(0.0125)$ \\
\hline \multirow[t]{2}{*}{ Building size } & 0.000390 & 0.000351 \\
\hline & $(0.000347)$ & $(0.000338)$ \\
\hline \multirow[t]{2}{*}{ French Naturalization } & -0.0906 & -0.0433 \\
\hline & $(0.0654)$ & $(0.0653)$ \\
\hline \multirow[t]{2}{*}{ European origin } & 0.0383 & 0.0506 \\
\hline & $(0.0925)$ & $(0.0905)$ \\
\hline \multirow[t]{2}{*}{ Maghrebian origin } & $-0.119 *$ & -0.102 \\
\hline & $(0.0676)$ & $(0.0679)$ \\
\hline \multirow[t]{2}{*}{ African origin } & 0.117 & 0.121 \\
\hline & $(0.138)$ & $(0.142)$ \\
\hline \multirow[t]{2}{*}{ Asian origin } & $-0.612^{* *}$ & $-0.617 * *$ \\
\hline & $(0.272)$ & $(0.308)$ \\
\hline \multirow[t]{2}{*}{ Other origin } & 0.561 & 0.623 \\
\hline & $(0.614)$ & $(0.634)$ \\
\hline \multirow[t]{2}{*}{ Unemployment rate } & & $1.178^{* * *}$ \\
\hline & & $(0.177)$ \\
\hline \multicolumn{3}{|l|}{ Socio-economic } \\
\hline Backgrounds of the area & No & Yes*** \\
\hline \multicolumn{3}{|l|}{ Department } \\
\hline Fixed effects & No & Yes*** \\
\hline \multirow[t]{2}{*}{ Constant } & $3.502^{* * *}$ & $3.719^{* * *}$ \\
\hline & $(0.291)$ & $(0.359)$ \\
\hline Observations & 4379 & 4379 \\
\hline R-squared & 0.082 & 0.137 \\
\hline
\end{tabular}

Robust standard errors adjusted for block clustering are in parentheses ${ }^{* * *} \mathrm{p}<0.01,{ }^{* *} \mathrm{p}<0.05,{ }^{*} \mathrm{p}<0.1$ 


\section{Alternative summary indices - Mean effect analysis}

As a robustness check, we have also experimented with alternative indices for measuring these three dimensions of housing conditions. We have first looked at basic indices defined as the sum of the outcome variables related to each dimension. For each of the three dimensions considered, we thus obtain a variable which increases with the number of adverse outcomes one faces. Table 14 reports the results of the regression of these three indices on ethnic and religious diversity for our favorite specification. Our results are robust to these alternative indices: the effect of ethnic diversity is still strongly significant for the index of Housing Quality, and is even stronger for the index for Neglect of Public Areas. As noticed previously, the reverse is true for civil conflicts. Now turning to religious diversity, column 2 shows that it only has a significant impact on the total amount of Neglect of the Public Areas, as observed in subsection 4.2.2.

Table 14: Diversity and Public goods: sum of the various outcomes, Public Housing

\begin{tabular}{|c|c|c|}
\hline & $\begin{array}{c}\text { Ethnic Diversity } \\
(1)\end{array}$ & $\begin{array}{c}\text { Religious dive } \\
(2)\end{array}$ \\
\hline \multicolumn{3}{|c|}{ 1. Neglect of the Public Areas } \\
\hline Sum of the outcome variables & $\begin{array}{c}2.321^{* * *} \\
(0.575)\end{array}$ & $\begin{array}{c}0.780^{* *} \\
(0.322)\end{array}$ \\
\hline \multicolumn{3}{|l|}{ 2. Quality of Housing } \\
\hline Sum of the outcome variables & $\begin{array}{c}1.511^{* * *} \\
(0.360)\end{array}$ & $\begin{array}{c}0.189 \\
(0.217)\end{array}$ \\
\hline \multicolumn{3}{|l|}{ 3. Civil Conflict } \\
\hline Sum of the outcome variables & $\begin{array}{c}0.029 \\
(0.059)\end{array}$ & $\begin{array}{c}0.008 \\
(0.043)\end{array}$ \\
\hline \multicolumn{3}{|l|}{ Socio-economic } \\
\hline Background of area & Yes*** & Yes*** \\
\hline Department fixed effects & Yes*** & Yes*** \\
\hline
\end{tabular}

Each coefficient is estimated from a separate regression, according to equation $|2|$ The three dependent variables considered are the three indices reported in bold. Each index is regressed on either ethnic diversity or religious diversity, controlling for the usual household and neighborhood characteristics unless otherwise indicated. Robust standard errors adjusted for block clustering are in parentheses. ${ }^{* * *} \mathrm{p}<0.01,{ }^{* *} \mathrm{p}<0.05$, $* \mathrm{p}<0.1$

To be more thorough, we next perform a mean effect analysis. Following Kling, Liebman and Katz (2007), we construct summary indices aggregating information across the various related outcomes for each of the three dimensions studied above. To build the three summary indices, we first normalize each outcome using a pseudo-control group defined by individuals living in blocks characterized by a below-median fractionalization index, as in Glennerster, Miguel and Rothenberg (2010). Let $Y_{k}$ be the $k^{t h}$ of $K$ related outcomes. Each standardized outcome $Y_{k}^{*}$ is obtained by subtracting the mean $\mu_{k}$ and dividing by the standard deviation $\sigma_{k}$ of the outcome variable among the low diversity pseudo-control group: $Y_{k}^{*}=\left(Y_{k}-\mu_{k}\right) / \sigma_{k}$. We then average the related standardized outcomes to form the summary index : $Y^{*}=\sum_{k} Y_{k}^{*} / K$.

Accordingly, our summary index for neglect of the commons averages nine standardized measures of graffiti, broken mailboxes, broken elevator, low care of the commons, voluntary degradations, garbage on the floor, ...; the index for poor housing conditions averages five standardized measures of quality of apartment's soundproofing, of efficiency of the heating system, and of the general state 
of the outside walls; finally the civil conflict indicator averages standardized measures of robbery and personal aggression.

Table 15: Components of Summary Indices, Public Housing

\begin{tabular}{lcccc}
\hline & \multicolumn{2}{c}{ Low ELF } & \multicolumn{2}{c}{ High ELF } \\
& \multicolumn{3}{c}{ - low ELF } \\
\cline { 2 - 5 } & $\begin{array}{c}\text { Raw } \\
(1)\end{array}$ & $\begin{array}{c}\text { Norm } \\
(2)\end{array}$ & $\begin{array}{c}\text { Raw } \\
(3)\end{array}$ & $\begin{array}{c}\text { Norm } \\
(4)\end{array}$ \\
\hline \hline & & & & \\
1. Neglect of the Public Areas & & & \\
Care of the commons & 1.49 & 0 & 0.14 & 0.19 \\
Sacking & 1.45 & 0 & 0.25 & 0.36 \\
Graffiti & 0.63 & 0 & 0.03 & 0.07 \\
Garbage on the floor & 0.42 & 0 & 0.08 & 0.16 \\
Broken glass & 0.31 & 0 & 0.06 & 0.13 \\
Broken doors & 0.32 & 0 & 0.01 & 0.01 \\
Broken light bulbs & 0.18 & 0 & 0.07 & 0.18 \\
Broken mailboxes & 0.33 & 0 & 0.09 & 0.19 \\
Broken elevators & 0.14 & 0 & 0.1 & 0.28 \\
& & & & \\
2. Quality of Housing & & & & \\
Condition of the outside walls & 2.42 & 0 & 0.01 & 0.01 \\
Quality of soundproofing & 1.83 & 0 & 0.23 & 0.28 \\
Noisy in daytime & 1.48 & 0 & 0.16 & 0.22 \\
Noisy in night time & 1.27 & 0 & 0.15 & 0.27 \\
Cold in the apartment & 0.14 & 0 & 0.08 & 0.23 \\
& & & & \\
3. Civil Conflict & & & & \\
Robberies & 0.08 & 0 & 0.01 & 0.05 \\
Aggressions & 0.06 & 0 & 0.02 & 0.08 \\
\hline
\end{tabular}

Table 15 presents the raw and normalized components of the three broad summary indices. The first column displays the mean of each outcome among the low-diversity group. The normalized outcomes for this pseudo-control group are displayed in column 2, with mean equal to zero by construction. Column 3 reports the difference between the mean of each outcome among the households living in high diversity neighborhoods (a treated group of sorts) and that among the low diversity population. The differences are all positive but one indicating that the average outcome is generally worse in more heterogeneous areas. Column 4 shows the difference between the normalized outcomes for treatment and control group, and allows for a more comprehensive reading. For instance, we know from column 3 that the raw difference between care of the commons in low and high diversity areas is of 0.14 . Column 4 now tells us that this difference is of 0.19 standard deviations, relative to the control group standard deviation. 
Table 16: Diversity and Public goods: mean effect estimates, Public Housing

\begin{tabular}{|c|c|c|}
\hline & $\begin{array}{c}\text { Ethnic Diversity } \\
(1)\end{array}$ & $\frac{\text { Religious dive }}{(2)}$ \\
\hline \multicolumn{3}{|c|}{ 1. Neglect of the Public Areas } \\
\hline Mean effect estimate & $\begin{array}{c}0.545^{* * *} \\
(0.130)\end{array}$ & $\begin{array}{c}0.180 * * \\
(0.073)\end{array}$ \\
\hline \multicolumn{3}{|l|}{ 2. Quality of Housing } \\
\hline Mean effect estimate & $\begin{array}{c}0.467^{* * *} \\
(0.107)\end{array}$ & $\begin{array}{c}0.076 \\
(0.065)\end{array}$ \\
\hline \multicolumn{3}{|l|}{ 3. Civil Conflict } \\
\hline Mean effect estimate & $\begin{array}{c}0.050 \\
(0.112)\end{array}$ & $\begin{array}{c}0.011 \\
(0.081)\end{array}$ \\
\hline \multicolumn{3}{|l|}{ Socio-economic } \\
\hline Background of area & Yes*** & Yes*** \\
\hline Department fixed effects & Yes*** & Yes*** \\
\hline
\end{tabular}

Each coefficient is estimated from a separate regression, according to equation 2 . The three dependent variables considered are the three summary indices indices reported in bold. Each index is regressed on either ethnic diversity or religious diversity, controlling for the usual household and neighborhood characteristics unless otherwise indicated. Robust standard errors adjusted for block clustering are in parentheses. *** $\mathrm{p}<0.01,{ }^{* *} \mathrm{p}<0.05,{ }^{*} \mathrm{p}<0.1$

Table 16 reports mean effect estimates from regressing the summary indices for negligence, quality of housing and civil conflicts on ethnic diversity and other variables, as in specification 2 . The coefficient on ethnic diversity is the mean effect size. As expected, for the negligence index and the quality of housing index, mean effect estimates of ethnic diversity are strongly positive (column 1). Using summary indices also allows us to compare the mean effect of diversity on those two normalized outcomes: lines 1 and 2 of Table 16 tell us that ethnic diversity has a more adverse impact on the neglect of common areas than on the average quality of housing. This gives us an insight concerning the mechanisms at play: high levels of ethnic diversity are more likely to generate uncivic behaviors that could be avoided with stronger social norms. By contrast, the mean effect estimate in the third line indicates that ethnic diversity plays no role on civil conflicts: in areas where diversity is exogenous, there is no significant impact of ethnic diversity.

The broad picture drawn in the three previous sets of regressions is largely confirmed by the regressions of each separate normalized outcome. The corresponding mean effect estimates of ethnic diversity are presented in table 17. Although diversity has no significant impact on a few outcomes, such as broken glass or broken light bulbs in the commons, we still have a very strong negative effect of diversity on every other negligence or housing quality outcome in the public sector. As noted earlier, the mean effects estimates for negligence outcomes are on average larger than those for housing quality. The effect measured on broken light bulbs is the strongest, with a more than one standard deviation difference between low and high diversity neighborhoods, while the lowest is obtained for the quality of sound proofing, with a difference of about one third in terms of standard deviations. Turning to civil conflicts, the mean effect estimates on robberies and direct aggressions are both insignificant in the public housing sector in our favorite specification. 
Table 17: Ethnic diversity and disaggregated housing outcomes : mean effects analysis, Public Housing

\begin{tabular}{|c|c|c|}
\hline & \multicolumn{2}{|c|}{ Ethnic diversity } \\
\hline & $(1)$ & $(2)$ \\
\hline \multicolumn{3}{|c|}{ 1. Neglect of the Public Areas } \\
\hline Care of the commons & $\begin{array}{c}0.752^{* * *} \\
(0.124)\end{array}$ & $\begin{array}{c}0.549^{* * *} \\
(0.164)\end{array}$ \\
\hline Sacking & $\begin{array}{c}1.271^{* * *} \\
(0.140)\end{array}$ & $\begin{array}{c}1.019^{* * *} \\
(0.183)\end{array}$ \\
\hline Graffiti & $\begin{array}{c}0.387^{* *} \\
(0.151)\end{array}$ & $\begin{array}{c}0.488^{* *} \\
(0.216)\end{array}$ \\
\hline Garbage on the floor & $\begin{array}{c}0.668^{* * *} \\
(0.162)\end{array}$ & $\begin{array}{c}0.625^{* * *} \\
(0.227)\end{array}$ \\
\hline Broken glass & $\begin{array}{c}0.475^{* * *} \\
(0.182)\end{array}$ & $\begin{array}{c}0.368 \\
(0.238)\end{array}$ \\
\hline Broken doors & $\begin{array}{c}0.228 \\
(0.176)\end{array}$ & $\begin{array}{c}0.110 \\
(0.241)\end{array}$ \\
\hline Broken light bulbs & $\begin{array}{c}0.878^{* * *} \\
(0.187)\end{array}$ & $\begin{array}{c}1.049^{* * *} \\
(0.248)\end{array}$ \\
\hline Broken mailboxes & $\begin{array}{c}0.652^{* * *} \\
(0.176)\end{array}$ & $\begin{array}{c}0.927^{* * *} \\
(0.239)\end{array}$ \\
\hline Broken elevators & $\begin{array}{c}0.694^{* * *} \\
(0.227)\end{array}$ & $\begin{array}{r}0.656^{* *} \\
(0.288)\end{array}$ \\
\hline 2. Quality of Housing & & \\
\hline Condition of the outside walls & $\begin{array}{c}0.629^{* * *} \\
(0.109)\end{array}$ & $\begin{array}{c}0.414^{* * *} \\
(0.151)\end{array}$ \\
\hline Quality of soundproofing & $\begin{array}{c}0.963^{* * *} \\
(0.099)\end{array}$ & $\begin{array}{c}0.393^{* * *} \\
(0.138)\end{array}$ \\
\hline Noisy in daytime & $\begin{array}{c}0.935^{* * *} \\
(0.110)\end{array}$ & $\begin{array}{c}0.613^{* * *} \\
(0.148)\end{array}$ \\
\hline Noisy in night time & $\begin{array}{c}1.096^{* * *} \\
(0.121)\end{array}$ & $\begin{array}{c}0.676^{* * *} \\
(0.159)\end{array}$ \\
\hline Cold in the apartment & $\begin{array}{c}0.634^{* * *} \\
(0.128)\end{array}$ & $\begin{array}{r}0.418^{* *} \\
(0.184)\end{array}$ \\
\hline 3. Civil Conflict & & \\
\hline Robberies & $\begin{array}{c}0.207^{* *} \\
(0.103)\end{array}$ & $\begin{array}{c}0.149 \\
(0.140)\end{array}$ \\
\hline Aggressions & $\begin{array}{c}0.231^{* *} \\
(0.104)\end{array}$ & $\begin{array}{r}-0.0489 \\
(0.149)\end{array}$ \\
\hline $\begin{array}{l}\text { Socio eco. background } \\
\text { and department. fixed effects }\end{array}$ & No & Yes \\
\hline
\end{tabular}

Each entry is the coefficient estimate on ethnic diversity from a separate regression.

All the regressions include controls for household characteristics.

Robust standard errors adjusted for block clustering are in parentheses. The components of the three summary indices are the variables listed below each of them. Descriptive statistics for these outcomes are in Table 8 *** $\mathrm{p}<0.01,{ }^{* *} \mathrm{p}<0.05,{ }^{*} \mathrm{p}<0.1$ 


\section{Regression results on separate outcomes}

Table 18: Diversity and Public goods: separate outcomes (public housing)

\begin{tabular}{|c|c|c|}
\hline & $\begin{array}{c}\text { Ethnic Diversity } \\
(1)\end{array}$ & $\begin{array}{c}\text { Religious diversity } \\
(2)\end{array}$ \\
\hline \multicolumn{3}{|l|}{ 1. Neglect of the public areas } \\
\hline Care of the common areas & $\begin{array}{c}0.397^{* * *} \\
(0.118)\end{array}$ & $\begin{array}{l}0.144^{*} \\
(0.073)\end{array}$ \\
\hline Sacking & $\begin{array}{c}0.710^{* * *} \\
(0.128)\end{array}$ & $\begin{array}{c}0.106 \\
(0.076)\end{array}$ \\
\hline Graffiti & $\begin{array}{c}0.234^{* *} \\
(0.104)\end{array}$ & $\begin{array}{c}0.069 \\
(0.056)\end{array}$ \\
\hline Garbage on the floor & $\begin{array}{c}0.309^{* * *} \\
(0.112)\end{array}$ & $\begin{array}{c}0.051 \\
(0.062)\end{array}$ \\
\hline Broken glass & $\begin{array}{c}0.169 \\
(0.109)\end{array}$ & $\begin{array}{c}0.048 \\
(0.062)\end{array}$ \\
\hline Broken doors & $\begin{array}{c}0.052 \\
(0.113)\end{array}$ & $\begin{array}{c}0.016 \\
(0.060)\end{array}$ \\
\hline Broken light bulbs & $\begin{array}{c}0.411^{* * *} \\
(0.097)\end{array}$ & $\begin{array}{l}0.024 \\
(0.055)\end{array}$ \\
\hline Broken mailboxes & $\begin{array}{c}0.436^{* * *} \\
(0.112)\end{array}$ & $\begin{array}{c}0.141^{* *} \\
(0.057)\end{array}$ \\
\hline Broken elevators & $\begin{array}{c}0.228^{* *} \\
(0.100)\end{array}$ & $\begin{array}{c}0.185^{* * *} \\
(0.053)\end{array}$ \\
\hline \multicolumn{3}{|l|}{ 2. Quality of Housing } \\
\hline Condition of the outside walls & $\begin{array}{c}0.393^{* * *} \\
(0.143)\end{array}$ & $\begin{array}{l}-0.075 \\
(0.086)\end{array}$ \\
\hline Quality of soundproofing & $\begin{array}{c}0.321^{* * *} \\
(0.112)\end{array}$ & $\begin{array}{c}0.078 \\
(0.068)\end{array}$ \\
\hline Noisy in daytime & $\begin{array}{c}0.431^{* * *} \\
(0.104)\end{array}$ & $\begin{array}{l}0.128^{*} \\
(0.066)\end{array}$ \\
\hline Noisy in night time & $\begin{array}{c}0.373^{* * *} \\
(0.088)\end{array}$ & $\begin{array}{l}0.136^{* *} \\
(0.056)\end{array}$ \\
\hline Cold in the apartment & $\begin{array}{r}0.148^{* *} \\
(0.065)\end{array}$ & $\begin{array}{c}0.030 \\
(0.034)\end{array}$ \\
\hline \multicolumn{3}{|l|}{ 3. Civil Conflict } \\
\hline Robberies & $\begin{array}{c}0.041 \\
(0.038)\end{array}$ & $\begin{array}{c}0.029 \\
(0.026)\end{array}$ \\
\hline Aggressions & $\begin{array}{l}-0.012 \\
(0.037)\end{array}$ & $\begin{array}{l}-0.020 \\
(0.024)\end{array}$ \\
\hline \multicolumn{3}{|l|}{ Socio-economic } \\
\hline Background of area & Yes*** & Yes*** \\
\hline Department fixed effects & Yes*** & Yes*** \\
\hline
\end{tabular}

Each coefficient is estimated from a separate regression, according to equation 2 . The three dependent variables considered are the three indices reported in bold. Each index is regressed on either ethnic diversity or religious diversity, controlling for the usual household and neighborhood characteristics unless otherwise indicated. Robust standard errors adjusted for block clustering are in parentheses. ${ }^{* * *} \mathrm{p}<0.01,{ }^{* *} \mathrm{p}<0.05$, $* \mathrm{p}<0.1$ 


\section{E. Description of the list of questions}

This section reports the list of questions, from the Housing Survey, used to construct the three indices "Neglect of Public Areas", "Poor Quality of Housing" and "Civil Conflicts".

\section{Neglect of Public Areas}

- In general, how would you qualify the care people take of the commons of your housing?

$1=$ Good, $2=$ Average, $3=$ Bad

- To what extent have you faced negligence or voluntary degradations in the commons of your housing during the last two months?

$1=$ Never, $2=$ Minor degradations, $3=$ Major or very frequent degradations

- Have you been witness to graffiti and degradations on the walls during the last two months?

- Have you been witness to trash and litter in the commons during the last two months?

- Have you been witness to broken windows during the last two months?

- Have you been witness to broken elevators during the last two months?

- Have you been witness to broken doors during the last two months?

- Have you been witness to broken light bulbs during the last two months?

- Have you been witness to degradations of mail boxes?

$0=$ No, $1=$ Yes

\section{Poor Quality of Housing}

- How does the facade of your building look?

$1=$ As new, $2=$ Good, $3=$ Average, dirty, $4=$ Bad, with cracks, $5=$ Very bad: building threatens to collapse

- Have you ever had a problem with the heating in your building during the last two months? $0=$ No, $1=$ Yes

- What is the condition of the soundproofing of your housing?

$1=$ Good, $2=$ Average, $3=$ Bad

- How frequently are you disturbed by the noise in your housing during the day?

- How frequently are you disturbed by the noise in your housing during the night? $1=$ Infrequently or never, $2=$ Rather frequently, $3=$ Very frequently

\section{Civil Conflicts}

- Have you, or a member of your household, been a victim or a witness to physical aggression in your neighborhood during the last twelve months?

- Have you, or a member of your household, been a victim or a witness to a robbery in your neighborhood during the last twelve months?

$0=$ No, $1=$ Yes 


\section{References}

[1] Alesina A., R. Baqir, W. Easterly, 1999: "Public Goods and Ethnic Divisions," Quarterly Journal of Economics, Vol. 114(4), pp. 1243-1284

[2] Alesina A., A. Devleeschauwer, W. Easterly, S. Kurlat, R. Wacziarg, 2003: "Fractionalization", Journal of Economic Growth, Vol. 8, 155-194

[3] Alesina, A. and E. La Ferrera, 2000: "Participation in Heterogeneous Communities", Quarterly Journal of Economics, Vol. 115(3), pp. 847-904

[4] Alesina, A. and E. La Ferrera, 2002: "Who trusts others?," Journal of Public Economics, Vol. 85(2): 207-234.

[5] Alesina, A. and E. La Ferrara, 2005: "Ethnic Diversity and Economic Performance", Journal of Economic Literature, Vol 43(3): 762-800

[6] Alesina, A. and E. Zhuravskaya, 2011: "Segregation and the Quality of Government in a Cross Section of Countries", American Economic Review, forthcoming

[7] Algan, Y., Mayer, T. and Thoenig, M., 2011: "The Economic Incentives of Cultural Transmission: Spatial evidence from Naming Patterns Across France", Sciences Po Working Paper

[8] Bernardot, M., 2008 : "Loger les immigrés", Bellecombe-en-Bauges, Rhône-Alpes: Editions du Croquant

[9] Coleman, J., 1988: "Social Capital in the Creation of Human Capital", The American Journal of Sociology, Vol. 94, supplement "Organizations and Institutions: Sociological and Economic Approaches to the Analysis of Social Structure", pp. S95-S120

[10] Combes, P.P., B. Decreuse, B. Schmutz, A. Trannoy, 2010: "The Neighbor is King: Customer Discrimination in the Housing Market", working paper

[11] Dancygier, R., 2010 : "Immigration and Conflict in Europe", Cambridge University Press

[12] Disdier, A. C., K. Head, T. Mayer, 2009: "Exposure to foreign media and changes in cultural traits: evidence from naming patterns in France", revised version of CEPR discussion paper No 5674

[13] Easterly, W., R. Levine, 1997: "Africa's growth tragedy: policies and ethnic divisions", Quarterly Journal of Economics, Vol. 112(4), pp. 1203-1250

[14] Fearon, J. D. and D. Laitin, 1996: "Explaining interethnic cooperation", American Political Science Review, Vol. 90(4), pp. 715-735

[15] Fryer, R. G., S. D. Levitt, 2004: "The Causes and Consequences of Distinctively Black Names", Quarterly Journal of Economics, Vol. 119(3), pp. 767-805

[16] Glennerster R., E. Miguel, A. Rothenberg, 2010: "Working Together: Collective Action in Diverse Sierra Leone Communities", Working Paper

[17] Goux, D., E. Maurin, 2006: "Close neighbours matter: neighbourhood effects on early performance at school", CEPR Discussion Paper No 5682 
[18] Katz, L. F., J. R. Kling, and J. B. Liebman, 2001: "Moving to Opportunity in Boston: Early Results of a Randomized Mobility Experiment," Quarterly Journal of Economics, CXVI 607-654

[19] Kling, J. R., J. B. Liebman and L. F. Katz, 2007: "Experimental Analysis of Neighborhood Effects", Econometrica, Vol. 75, No. 1, pp. 83-119

[20] Miguel, E., 2004: "Tribe or nation?: Nation building and public goods in Kenya versus Tanzania" World Politics, Vol 56(3), pp. 327-362

[21] Miguel, E. and M. K. Gugerty, 2005: "Ethnic Diversity, Social Sanctions, and Public Goods in Kenya", Journal of Public Economics, Vol 89 (11), pp. 2325-2368

[22] Oreopoulos, P., 2003: "The long run consequences in working in a poor neighborhood", Quarterly Journal of Economics, Vol. 118(4), pp. 1533-1575

[23] Page, S.E., 2007: "The Difference: How the Power of Diversity Creates Better Groups, firms, Schools, and Societies", Princeton University Press

[24] Posner, D., 2004: "The Political Salience of Cultural Difference: Why Chewas and Tumbukas are Allies in Zambia and Adversaries in Malawi", American Political Science Review, Vol. 98(4), pp. 529-545

[25] Putnam, R., 2007: "E Pluribus Unum: Diversity and Community in the twenty-first Century", Scandinavian Political Studies, Vol 30(2), pp. 137-74.

[26] Rouquette, R., H. Lipietz, 1991: "Droit du Logement Social", Editions du Moniteur

[27] Simon, P., 2003: 'Le logement social en France et la gestion des 'populations à risques' ", Hommes et Migrations, No. 1246, pp. 76-91.

[28] SOS-Racisme, 2009: "Le Fichage Ethno-Racial = Un Outil De Discrimination", rapport de Samuel Thomas, président de la Fédération Nationale des Maisons des Potes et Vice Président de SOS Racisme réalisé dans le cadre de la « convention relative au fichage territorial ou ethnique pouvant conduire à des pratiques discriminatoires de recrutement dans les entreprises » du 13 novembre 2008.

[29] Tabard, N. 2002 : "Inégalités et disparités entre les quartiers en 1999", in Géraldine Martin-Houssart, Données sociales, La société française.

[30] Vigdor, J. (2002) : "Interpreting ethnic fragmentation effects", Economic Letters $n^{\circ} 75$, $271-276$ 